NBER WORKING PAPER SERIES

\title{
THE EFFECTS OF MULTINATIONAL PRODUCTION ON WAGES AND WORKING CONDITIONS IN DEVELOPING COUNTRIES
}

\author{
Drusilla K. Brown \\ Alan V. Deardorff \\ Robert M. Stern \\ Working Paper 9669 \\ http://www.nber.org/papers/w9669
NATIONAL BUREAU OF ECONOMIC RESEARCH
1050 Massachusetts Avenue
Cambridge, MA 02138
April 2003

Presented at NBER/CEPR/SNS Conference, International Seminar on International Trade (ISIT), "Challenges to Globalization," Höberge Gård, Stockholm, May 24-25, 2002. The views expressed herein are those of the authors and not necessarily those of the National Bureau of Economic Research.

(C2003 by Drusilla K. Brown, Alan V. Deardorff, and Robert M. Stern. All rights reserved. Short sections of text not to exceed two paragraphs, may be quoted without explicit permission provided that full credit including Cnotice, is given to the source. 
The Effects of Multinational Production on Wages and

Working Conditions in Developing Countries

Drusilla K. Brown, Alan V. Deadorff, and Robert M. Stern

NBER Working Paper No. 9669

April 2003

JEL No. F2

\begin{abstract}
This paper assesses the evidence regarding the effects of multinational production on wages and working conditions in developing countries. It is motivated by recent controversies concerning whether multinational firms in developing countries exploit workers by paying low wages and subjecting them to substandard conditions. We first address efforts of activist groups, universities, and colleges in the "Anti-Sweatshop" Campaign in the United States, the social accountability of multinational firms, and the role of such international institutions as the International Labor Organization and World Trade Organization in dealing with labor standards and trade. We then consider conceptually how foreign direct investment might affect host-country wages. Available theories yield ambiguous predictions, leaving the effects to be examined empirically. We therefore, finally, review empirical evidence on multinational firm wages in developing countries, and the relationship between foreign direct investment and labor rights. This evidence indicates that multinational firms routinely provide higher wages and better working conditions than their local counterparts, and they are typically not attracted preferentially to countries with weak labor standards.
\end{abstract}

Drusilla K. Brown

Department of Economics

Tufts University

Medford, MA 02155
Alan V. Deardorff

Department of Economics University of Michigan

Ann Arbor, MI 481091220
Robert M. Stern

Department of Economics

University of Michigan

Ann Arbor, MI 48109-

1220 


\title{
The Effects of Multinational Production on Wages and Working Conditions in Developing Countries
}

\author{
Drusilla K. Brown, Tufts University \\ Alan V. Deardorff, University of Michigan \\ Robert M. Stern, University of Michigan
}

\section{Introduction}

This paper is designed to assess the empirical evidence on the effects of multinational production on wages and working conditions in developing countries. It is motivated by the controversies that have emerged especially in the past decade or so concerning whether or not multinational firms in developing countries are exploiting their workers in "sweatshop" conditions by paying low wages and subjecting them to coercive, abusive, and unhealthy and unsafe conditions in the workplace. Thus, in Section II, we address these controversies in the context of the efforts and programs of social activist groups and universities and colleges involved in the "Anti-Sweatshop" Campaign in the United States and the related issues of the social accountability of multinational firms and the role of such international institutions as the International Labor Organization (ILO) and World Trade Organization (WTO) in dealing with labor standards and trade. We then turn more broadly in Section III to a conceptual treatment of the effects of foreign direct investment (FDI) on wages in host countries and the effects of outsourcing and subcontracting by multinational firms. Thereafter, the empirical evidence on multinational-firm wages in developing countries is reviewed in Section IV, together with evidence on the relationship between FDI and labor rights. Conclusions are presented in Section V.

\section{Political Economy Issues}

As mentioned, our paper has been motivated by the controversies as to whether multinational firms are exploiting and mistreating their workers by employing them under "sweatshop" conditions. What this

\footnotetext{
We wish to thank Robert Baldwin, Elliot Berg, Rob Howse, Rachel McCulloch, Ian Robinson, André Sapir, participants in the NBER pre-conference meeting, and participants in the NBER/CEPR/SNS Stockholm conference, as well as seminar participants at the University of Michigan and the University of Leuven, for their helpful comments on earlier versions of our paper. We also thank Gladys Mitchell for research assistance and Judith Jackson for editorial and typing assistance.
} 
means is exploiting the workers by paying low wages and subjecting them to violations of certain universal social norms or standards governing their employment. In this connection, Moran (2002) has stressed the importance of distinguishing low-wage, relatively unskilled labor-intensive industries such as apparel and footwear from industries that employ more highly skilled workers and produce relatively more skillintensive products such as electronics and automotive products. Many social activists and activist organizations that are critical of multinational wages and working conditions in developing countries do not make this distinction. Rather, much of the criticism by social activists in the United States especially has been directed at multinational operations in the apparel and footwear industries that are allegedly producing under "sweatshop" conditions. ' We turn next accordingly to consider the salient anti-sweatshop issues.

\section{The Anti-Sweatshop Campaign in the United States}

Elliot and Freeman (2001, pp. 15-16) note that:

"Sweatshops have characterized apparel production since industrial revolution days, and so too have campaigns to improve labor conditions in the industry. ...Many of the issues are the same, but a major difference between anti-sweatshop campaigns at the turn of the $21^{\text {st }}$ century and those at the turn of the $20^{\text {th }}$ century is that sweatshops then were largely local whereas today they are found mostly in poor developing countries. This means that U.S.-based activists cannot lobby the U.S. government to improve labor standards. Instead they must target U.S.-based corporations who operate or source in developing countries or pressure the world trading community to demand changes in less developed countries."

${ }^{1}$ Graham (2000, pp. 101-102) has noted that products originating in the footwear, apparel, toy-making, and sporting goods industries combined accounted for less than 10 percent of world merchandise exports in 1997. He then states: "If indeed sweatshop conditions are concentrated in these industries, they do not represent the greater part of globalized economic activity." It would be more meaningful, however, to consider how important the exports of these goods are for developing countries, rather than for the world as a whole. Graham's source, WTO (1998), does not report trade by level of development. But its geographic data are suggestive: WTO(2000) reports textile exports as a percent of manufactured exports to be only 2.3\% for Latin America, 3.6\% for Africa, and $6.9 \%$ for Asia excluding Australia, Japan, and New Zealand.

${ }^{2}$ Robert Baldwin has pointed out to us that the unfavorable perception of FDI, and industrialization in general, may be related historically to the change from a household to a factory system of production. Thus, one does not usually think of a family engaged in household production as working under sweatshop conditions. It is mainly when workers are assembled to produce in factories that it is believed that they may be subjected to sweatshop conditions, even though their wages may be higher and children may have more access to education and better medical care. 
Elliot and Freeman (2001, pp. 48-49) provide a timeline of U.S. anti-sweatshop activities from 1990 to spring $2000{ }^{3}$ and a list of transnational labor rights activist organizations (Appendix Exhibit A). As they note (pp. 16-17), during this period, multinationals such as Levi Strauss, Gap, PhillipsVanHeusen, and others were singled out for condoning undesirable labor practices. And Wal-Mart, a major retailer, was cited as selling clothing made by child labor in Bangladesh and Honduras. Many of the firms involved in producing or sourcing abroad have responded to the criticisms by adopting codes of conduct that are designed presumably to guide their operations. ${ }^{4}$ In 1996, the Clinton Administration established the Apparel Industry Partnership (AIP) to address sweatshop issues globally by bringing together apparel firms, unions, and NGOs by means of a code of conduct and a monitoring system that were introduced in April 1997 and that would be applicable to the firms involved. Subsequently, in November 1998, the AIP established the Fair Labor Association (FLA) to implement and monitor the code. Some groups, in particular the Union of Needletrades, Industrial and Textile Employees (UNITE), were critical of the AIP/FLA program, complaining as Elliott and Freeman note (p. 17) that “...the code failed to require payment of a living wage; had weak language with respect to union rights in nondemocratic countries; and had a weak monitoring and verification system." Nonetheless, by fall 2000, 140 colleges and universities had become affiliated with the FLA, and, as of the end of 2001, the number had grown to $192 .^{5}$

It was during this period that student activism on sweatshops took hold at a number of American campuses. A group called Students Against Sweatshops was established at Duke University in August 1997. With assistance from UNITE, the United Students Against Sweatshops (USAS) was established on a national basis in summer 1998. In expressing their dissatisfaction with the FLA, the student members of the USAS orchestrated sit-ins during 1999 at a number of prominent universities and colleges. On Oc-

\footnotetext{
${ }^{3}$ See also Varley (1998, pp. 12-13).

${ }_{5}^{4}$ We have more to say on this below.

${ }^{5}$ The list of colleges and universities affiliated with the FLA can be found at [www.fairlabor.org/htm/affiliates/unversity.html].
} 
tober 19, 1999, the USAS announced the creation of the Worker Rights Consortium (WRC) and urged institutions to withdraw from the FLA and join the WRC, which purportedly had a stronger code of conduct, a focus on worker complaints and education on worker rights, and a requirement for disclosure of the name and location of factories producing licensed apparel. As of June 2000, 50 institutions had become affiliated with the WRC. The number had grown to 92 as of December 13, 2001, and 49 of these institutions continued to remain affiliated with the FLA. ${ }^{6}$

Elliott and Freeman (2001, p. 18) note that a number of additional organizations were created that formulated codes of conduct and mechanisms for monitoring adherence to the codes. These organizations include such U.S. groups as: Social Accountability International, which administers its SA8000 code on a global and multi-industry basis; the Collegiate Licensing Company (CLC); the Worldwide Responsible Apparel Production (WRAP); and Verité, which monitors human rights especially. There is also the Europe-based Ethical Trade Initiative, and there are NGOs based in developing countries. There are a number of private monitoring groups, including PriceWaterhouseCoopers (PWC) and Ernst and Young. In addition, many American academic institutions have established codes of conduct, ${ }^{7}$ although they depend for the most part on the monitoring to be carried out by the FLA or WRC. ${ }^{8}$ It is of interest therefore to compare the main features of the FLA and WRC.

\section{Comparison of the FLA and WRC}

As noted above, the FLA was established in 1998 as an outgrowth of the Apparel Industry Partnership (AIP) sponsored by the Clinton Administration. Its focus is on improving working conditions in the

\footnotetext{
${ }_{7}^{6}$ The list of institutions affiliated with the WRC can be found at [www.workersrights.org/as.asp].

${ }^{7}$ See, for example, the University of Michigan code of conduct in University of Michigan Advisory Committee on Labor Standards and Human Rights (2000, pp. 7-8).

${ }^{8}$ It is noteworthy that the University of Chicago decided against joining either organization. According to the University of Chicago Magazine (2000), they opted to rely on Barnes \& Noble, which operates the University bookstore locations, to require that all merchandise sold complies with FLA standards.
} 
global apparel industry. ${ }^{9}$ In considering the relative merits and membership in the FLA and WRC, the University of Michigan Advisory Committee on Labor Standards and Human Rights (2000, pp. 30-33) noted for example the following positive features of the FLA: (1) the FLA membership includes most of the largest apparel producers, is well funded, may be cost effective in avoiding the proliferation of codes of conduct and monitoring, and may provide economies of scale in coordinating its membership and carrying out monitoring; (2) the FLA focuses on the apparel industry as a whole, and its charter gives universities the option to pursue more flexible strategies if so desired. Some of the concerns expressed about the FLA were that it might be dominated by corporate interests that would favor a weak code of conduct on such issues as health and safety, women's rights, compensation, and hours and overtime, and that it would be reluctant to provide public disclosure of factory locations.

With regard to the WRC, the Michigan Advisory Committee Report (2000, pp. 29-31) cited the following attractive features: ${ }^{10}$ (1) emphasis on disclosure, transparency, and public information on conditions in apparel factories; (2) emphasis on the investigation of complaints as a means of focusing attention on factories where problems are reported rather than relying on monitoring per se; (3) commitment to involve workers and their representatives in the development and implementation of WRC policies; (4) insistence on including a living-wage standard in the WRC code of conduct to focus the attention of universities and licensees on wage issues; (5) concentration on university-licensed apparel rather than on the entire apparel industry as a means of enhancing the leverage of universities; and (6) independence from the FLA and other groups as a means of providing a check on the quality and reliability of other monitoring efforts. Some concerns expressed about the WRC were: (1) its adversarial approach towards licensees, with the consequence that licensees may view the WRC with suspicion, make them hesitant in selfreporting their activities, undermine the credibility and legitimacy of the WRC investigation of reported complaints, and disrupt university-business relationships with licensee partners; (2) the WRC objective of

\footnotetext{
${ }^{9}$ The code of conduct of the FLA can be found at www.fairlabor.org.

${ }^{10}$ The code of conduct of the WRC can be found at www.workersrights.org.
} 
educating workers and encouraging them to act on their own rights may compromise the impartial and independent investigation of worker complaints; (3) there may be an over-reliance on complaint investigation insofar as it presumes that workers are aware of their rights and willing to take risks in filing complaints; and (4) that the independence and credibility of the WRC may be compromised because of the presence on its Governing Board of UNITE or other U.S. unions with a documented history of trade protectionism and discouragement of apparel job creation in developing countries. ${ }^{11}$

From the perspective of many American colleges and universities, it should be evident from the foregoing discussion that there are some important differences between the FLA and WRC in terms of their objectives and mode of operation. Two issues that stand out are deserving of further comment: (1) the living wage; and (2) conditions of work, including the right of association and collective bargaining.

The Living Wage

As noted in www.fairlabor.org, the FLA code relating to wages and benefits is:

"Wages and Benefits. Employers recognize that wages are essential to meeting employees' basic needs. Employers shall pay employees, as a floor, at least the minimum wage required by local law or the prevailing industry wage, whichever is higher, and shall provide legally mandated benefits."

As noted in www.workersrights.org, the WRC code relating to wages and benefits is:

"1. Wages and Benefits: Licensees recognize that wages are essential to meeting employees' basic needs. Licensees shall pay employees, as a floor, wages and benefits which comply with all applicable laws and regulations, and which provide for essential needs and establish a dignified living wage for workers and their families. [A living wage is a "take home" or "net" wage, earned during a country's legal maximum work week, but not more than 48 hours. A living wage provides the basic needs (housing, energy, nutrition, clothing, health care, education, potable water, childcare, transportation and savings) of an average family

\footnotetext{
${ }^{11}$ In this regard, it is of interest to note the statement in the University of Chicago Magazine (2000):

"It is the WRC's apparent intention to move beyond a monitoring function to an advocacy role - supporting particular social, political, and environmental positions - that troubles the University administration and faculty.... As ... outlined by the faculty in the 1967 Kalven Committee Report on the University's Role in Political and Social Action: "A university ... is a community but only for the limited, albeit great, purposes of teaching and research. It is not a club, it is not a trade association, it is not a lobby."”
} 
unit of employees in the garment manufacturing employment sector of the country.]"

It is evident that the WRC concept of what constitutes a living wage is much more explicit than the FLA basic-needs criterion of the payment of the minimum wage or prevailing industry wage, whichever is higher. As noted by Elliott and Freeman (2001, p. 50), the WRC is apparently willing to postpone the implementation of its living-wage standard pending the completion of further research. This is essentially similar to the position of the FLA, which called for a wage study that was carried out by the U.S. Department of Labor (2000) and a request for follow up on this study with possible annual updates. ${ }^{12}$ In any event, the question at issue is how to define and measure what constitutes a living wage or basic needs and how this relates to the wages that workers are actually receiving.

The information on wages that we will present in Section IV below suggests that there is pervasive evidence that workers employed in multinational firms and subcontracting in developing countries are being paid wages that are on average higher than compared to alternative employment domestically. Of course, these wages are low in absolute terms in comparison with wages of workers in developed countries. Granting this, many observers have argued that workers' wages in developing countries may not be sufficient to satisfy basic needs. Hence the pressure for higher wages.

In this connection, for example, a group of students from the Columbia University School of International and Public Affairs carried out a study in 1999 for the National Labor Committee to calculate a living wage for maquila workers in El Salvador — see Connor et al. (1999). They found that most maquila workers earned the legal monthly minimum wage of 1,260 colones, which was estimated to be barely sufficient to meet basic food requirements. According to the formula used, it was estimated that maquila workers in El Salvador required a living wage of 4,556 colones to cover the basic needs of a family of 4.3 people living on one wage and allowing for 12.5 percent to be saved for the future. It was recommended that the process for setting wages according to a living-wage formula be standardized and multinational firms should adopt industry-wide standards for paying a living wage.

\footnotetext{
${ }^{12}$ See www.fairlabor.org/html/faqs.html.
} 
Moran (2002, Ch. 4, pp. 10-12) has pointed out the extraordinary complexities involved in calcu-

lating a living wage:

(1) There is a need to determine the nutritional standards, types of housing, expenditure categories, savings, and provisions for contingencies to be included in the living-wage formula and to make allowance for inter-country differences in purchasing-power-parity and macroeconomic conditions.

(2) Estimates of family size as a basis for wage adequacy may be arbitrary and discriminatory since average family size may vary, and there may be differences among wage earners depending on their age, gender, and family relationships.

Using South Asia as an example, Srinivasan (2001) also questions the relevance of attempting to

calculate and administer a living wage. He notes that:

(1) in South Asia, over half of the labor force is self employed and the proportion of regularly employed wage-paid workers is small;

(2) workers employed by multinationals are generally well paid, unionized, have legal protection of their rights, and receive mandated benefits, so that payment of a living wage to these workers may be redundant;

(3) focusing on paying a living wage to workers employed by multinationals diverts attention from the far more serious and relevant problem of poverty and from the need to promote rapid economic growth to help eradicate poverty; and

(4) the goal of the living-wage proponents would be better served if they would lobby to eliminate barriers in developed countries on imports of labor-intensive manufactures and other trade barriers more generally, and relax immigration restrictions on unskilled workers. By the same token, efforts should be made in developing countries themselves to eliminate bureaucratic corruption, remove barriers to trade, and dismantle domestic policies that are inimical to the poor.

While living-wage proponents may grant many of the foregoing objections, they commonly argue

nonetheless that multinationals can well afford to pay higher wages to workers in developing countries because those wages are typically but a tiny fraction of the selling price of the product. In this connection, some examples noted in Moran (2002, Ch. 4, pp. 15-16) are of interest: in 2000, the piece rate plus benefits of jeans produced in Nicaragua was $\$ .66$ compared to the U.S. retail sales price of $\$ 21.99$; in 2000, the unit labor cost, inclusive of benefits, for a ladies jacket made in Hong Kong was \$.84 compared to the U.S. retail price of $\$ 99$; in 2001 , the unit wage was $\$ .40$ for a sport shoe produced in Indonesia that sold for $\$ 100$ in the United States; and, in 2001, Nike reported that the labor cost of Nike shoes was $\$ 2.43$ compared to a retail price of $\$ 65$. 
What are we to make of these comparisons? One can argue that the comparisons are inappropriate because they do not take into account the costs of further processing, transportation, advertising, and distribution. There is also a presumption that the multinational firms may be capturing oligopoly rents because of brand preferences, private labels, and name recognition that they have established. While it is conceivable that some of the largest multinationals may be capturing oligopoly rents, it is unclear how pervasive this is especially for firms competing at the retail level. But suppose for the sake of argument that some multinationals are mandated or may opt to divert some of their profits to pay higher wages to their workers in developing countries. It is by no means clear exactly how this would be done and what would prevent the companies from shifting their operations to locations with already higher wages and higher productivity.

The difficulty of paying higher wages would be even more pronounced if subcontracting firms were obliged to do so. Thus, as Moran notes (p. 16), in the examples cited above, the local wage bill ranged from 20 percent of the pre-tax profit for the firm producing footwear in Indonesia, 46 percent for the jeans production in Nicaragua, and 250 percent for the Nike shoes. Since subcontracting firms are generally independently owned, mandating higher wages for them in these circumstances would almost surely motivate them to search out less costly production locations.

The view that mandating higher wages for workers in developing countries can be accomplished with minimum disruption to employment within and between countries has been colored by the research finding of Card and Krueger (1995) that increases in the minimum wage in the United States in the early 1990s did not reduce teenage employment. In our judgment, contrary to Card and Krueger, there is reason to believe that labor-intensive manufacturing in developing countries is relatively sensitive to changes in wage levels. This is particularly true for the production of apparel and footwear, which are prototype "footloose" industries. This is borne out for example by the experiences of Japan and the Asian TigersHong Kong, Singapore, South Korea, and Taiwan - insofar as increased labor costs in these countries in the course of their economic expansion from the 1960s onward resulted in a shift of the location of laborintensive industries to China and Southeast Asia and to some extent to South Asia. Also worth mention- 
ing are the experiences of Mauritius and Madagascar noted by Moran (2002, Ch. 4, p. 9), which suggest that labor-intensive producers were sensitive to changes in relative wage levels in deciding where to expand or contract employment and change the location of production. ${ }^{13}$ More recently, there have been news reports about maquiladora factories closing down in Mexico and moving to Asia or Eastern Europe, and garment and shoe-manufacturing orders being lost in Indonesia to competitors in China and Vietnam where wages are lower and quality and delivery schedules more reliable. ${ }^{14}$

A common response to this argument - that mandating a living wage will cause employers to change locations - is to say that the living wage should be mandated in all countries, not just a few, so that there is no place for employers to go. But this misses the point. Wages vary across countries due to differences in labor productivity, which typically rises with the level of development. However the living wage may be defined, it will be above the productivity-based market wages in some countries and below that in others. If employers are required to pay the living wage, they will tend to move to countries where the living wage is justified by productivity. ${ }^{15}$

We conclude therefore that efforts to define and measure the living wage are fraught with insuperable difficulties, ${ }^{16}$ and that it is likely that the imposition of a living wage that exceeds existing marketdetermined wage levels will result in employment shifts in developing countries that would be detrimental to economic efficiency and welfare. ${ }^{17}$

\footnotetext{
${ }^{13}$ See also Cooper (2001) for a journalistic account of the experiences of the two countries.

${ }^{14}$ See The New York Times (June 29, 2002, p. A3) and The Wall Street Journal (August 14, 2002, p. A17).

${ }^{15}$ In an econometric study of the effects of labor costs on foreign direct investment (FDI), while controlling for labor productivity, Kucera $(2001$, p. 28 ) has noted that "...coefficients of the wage share [of value added] variable are more and significantly negative for LDCs..." and that "...a 10 percent increase in wage share would be associated with a 6.6 to 8.5 percent decline in FDI inflows in LDCs, compared with a 4.3 to 5.8 percent decline for all countries."

${ }^{16}$ The most comprehensive effort to define and measure the living wage is to be found in U.S. Department of Labor (2000). Their conclusion (p. vi) is: "For the countries considered, there appears to be little conclusive evidence on the extent to which wages and non-wage benefits in the footwear and apparel [industries] meet workers' basic needs."

${ }^{17}$ Neumark (2002) has studied the effects of living wage ordinances that have been adopted in many cities across the United States. These ordinances typically mandate a minimum wage floor that is often considerably higher than the traditional minimum wages set by state and federal legislation. Among the most significant findings are the following: (1) living wage ordinances have sizable positive effects on the wages of low-wage workers; (2) employment is
} 


\section{The Right of Association and Collective Bargaining}

As noted in www.fairlabor.org, the pertinent FLA code is:

"Freedom of Association and Collective Bargaining. Employers shall recognize and respect the right of employees to freedom of association and collective bargaining."

The pertinent WRC code noted in www.workersrights.org is:

"9. Freedom of Association and Collective Bargaining: Licensees shall recognize and respect the right of employees to freedom of association and collective bargaining. No employee shall be subject to harassment, intimidation or retaliation in their efforts to freely associate or bargain collectively. Licensees shall not cooperate with governmental agencies and other organizations that use the power of the State to prevent workers from organizing a union of their choice. Licensees shall allow union organizers free access to employees. Licensees shall recognize the union of the employees' choice."

The right of association and collective bargaining is arguably the most contentious of issues in countries with low-wage labor and specialization in labor-intensive industries like apparel and footwear.

As Moran (2002, Ch. 3, p. 14) notes, the problems include: (1) the representation of workers and antiunion discrimination: (2) the right to strike; and (3) the threat to close plants that form unions.

Many employers have initiated worker-management associations designed to foster good relations with employees, and, according to Moran (p. 15), there is evidence for example in the Philippines, Dominican Republic, and Costa Rica of relatively high wages and good treatment of workers. By the same token, there have been allegations and evidence offered of cases of discrimination against workers seeking to organize unions in a number of countries. ${ }^{18}$ This has been a problem especially when there already exists a government sponsored or government favored union, or when unions are prohibited by the

reduced among the affected workers; (3) a detectable number of families may be lifted above the poverty line, even allowing for employment reductions; and (4) unionized municipal workers especially may gain from narrow living wage laws covering city contractors. Thus, while there is some evidence that living wages may provide some assistance to the working poor, Neumark notes that such ordinances may not be the best policy for helping the urban poor and that a range of other issues needs to be addressed, including budget implications, the incidence of the measures, effects on taxes and local development, the provision of city services, productivity, compliance and enforcement, and equity and overall economic welfare. See also the variety of comments on Harvard's living-wage debate in Harvard Magazine (2001).

${ }^{18}$ A recent example is a strike by about 800 workers making collegiate apparel for Nike in the Korean owned factory, Kukdong International Mexico, located in Atlixco, Mexico, after some of their fellow workers had been fired in connection with their involvement in labor-rights disputes. For more information, see Verité (2001). 
government. Moreover, workers have been dismissed in some cases for participating in strikes, and replacement workers have been hired. Further, the threat to close plants that form unions has been alleged to occur at times.

There are divergent views on the issues of the right of association and collective bargaining. Thus, it can be argued that encouragement of unions and collective bargaining may enhance the efficiency of labor markets and increase the productivity of workers, especially when there are monopsonistic employers. $^{19}$ There may also be significant political and social spillover effects as democratic institutions and social harmony are strengthened. Further, it may be the case that governments are weak so that there is nobody to protect the workers but the workers themselves. On the other hand, as noted in the above discussion of the living wage, it may be the case in many low-income countries that labor unions are already concentrated in the formal manufacturing sector, and there may be substantial numbers of workers employed in public enterprises. As a consequence, the fostering of unions could be harmful to workers and families in the informal and in the rural/agricultural sectors that would have to absorb the workers displaced from these organized sectors. This is where much of the labor force is self employed, often doing "home work" on a piece-rate basis, and the numbers of regularly employed wage-paid workers may be limited.

The point just made should not be construed as condoning the suppression of unions and worker rights. Rather, the issue is whether the right of association and collective bargaining should be considered to be the prime objective, as emphasized by the WRC, to enhance the welfare of workers in low-income countries. That is, account needs to be taken of the wages and benefits that workers are actually receiving together with the treatment that they are being accorded in the workplace. Thus, as Moran (2002) in particular has stressed, there is considerable evidence suggesting that market forces combined with judicious

\footnotetext{
${ }^{19}$ See, for example, Freeman (1993).

${ }^{20}$ In this connection, Srinivasan (1998, p. 239) has remarked: “... where the freedom to form unions has been exercised to a considerable extent, namely in the organized manufacturing and public sectors in poor countries, labor unions have been seen promoting the interests of a small section of the labor force at the expense of many. ... it should be recognized ... that unionized labor often constitutes a small labor aristocracy in poor countries."
} 
government policies can provide the basis for enhancing worker welfare in poor countries. There may well be cases in which workers are mistreated in terms of not receiving their rightful wages or are subjected to poor working conditions. ${ }^{21}$ In these instances, corrective measures should be taken by government in conformity with domestic law.

\section{The ACIT and SASL Initiatives}

We have had occasion in the preceding discussion to review the issues that are pertinent to the Antisweatshop Campaign that has focused attention on the wages and working conditions in multinational firm operations in the apparel and footwear industries in low-income countries. Much of this campaign is being played out in the efforts of organizations like the WRC and the FLA to provide codes of conduct and monitoring of firms engaged in the production and marketing of apparel and related items bearing university and college logos.

As mentioned above, the strategy of the WRC and associated student groups has been one of confrontation with university/college administrations in the form of protests and sit-ins that were resolved in most cases by agreeing to membership in the WRC. At the same time, the FLA has been active in its efforts to engage and induce universities and colleges to become FLA members. As noted above, the FLA had 192 members at the end of 2001. The WRC had 92 members, and 49 of them were also members of the FLA.

Following the failure of the WTO Ministerial Meeting in Seattle in December 1999, Jagdish Bhagwati of Columbia University and Robert M. Stern of the University of Michigan convened a group of academic international trade economists and lawyers that met in January 2000 at the Georgetown University Law Center. The objective of the meeting was an effort to review what had happened in Seattle and the role that academic trade specialists might play in bringing their expertise to bear on the important issues of trade policy and engaging the attention of policy makers and the public. After the Georgetown

\footnotetext{
${ }^{21}$ For documentation, see, for example, Business for Social Responsibility Education Fund et al. (2000) and Verité (2000).
} 
meeting, it was decided to establish the Academic Consortium on International Trade (ACIT) with the foregoing objectives in mind. An ACIT Steering Committee was established and comprised: Robert E. Baldwin, University of Wisconsin; Jagdish Bhagwati, Columbia University; Alan V. Deardorff, University of Michigan; Arvind Panagariya, University of Maryland; T. N. Srinivasan, Yale University; and Robert M. Stern, University of Michigan, as Head of the Steering Committee. An ACIT website [www.Fordschool.umich.edu/rsie/acit] was created as a repository for academic papers, reports, policy statements, and news articles dealing with trade policy and related issues.

One of the most contentious issues at the Seattle Ministerial Meeting was that of trade and labor standards. This is a topic that most of the members of the ACIT Steering Committee had addressed individually and jointly in their published theoretical and policy-oriented writings. These writings explored the analytical complexities, political economy, empirical evidence, and the policies of national governments and international organizations involving trade and labor standards. The ACIT group concluded that much of the social activism in the United States regarding labor standards was motivated by protectionist considerations especially on the part of organized labor. The interests of low-income, developing countries were seen therefore to be especially at risk, particularly if efforts were made to mandate higher labor standards, including higher wages, by means of trade sanctions or other pressures on low-income countries.

It was with these concerns in mind that the ACIT Steering Committee decided to address the decisions taken by university and college administrators to design codes of conduct on their own and/or to become affiliated especially with the WRC to deal with issues of sweatshop labor. The ACIT Steering Committee prepared a letter that was sent in September 2000 to around 600 university and college presidents, stating that the actions taken or to be taken on sweatshop issues at many institutions were possibly not well informed and therefore ill advised. This letter is available on the ACIT website and in Broad (2002, pp. 222-23). It was first circulated to academic trade specialists and other members of the academic community, and some 352 (primarily) economists and other academics indicated that they wished to be signatories of the letter. The list of signatories is available on the ACIT website. 
It is noteworthy that only a small number of university presidents or administrators acknowledged receipt of the letter. These included Columbia, Duke, UC-Berkeley, Harvard, and some smaller institutions. But what is perhaps more significant is that the ACIT letter received considerable press and media coverage, much of which can be found on the ACIT website.

It stands to reason that some members of the academic community would take issue with the position expressed in the ACIT letter. Thus, a group calling itself Scholars Against Sweatshop Labor (SASL) was formed, and they prepared a letter that was endorsed by 434 signatories (73 percent economists) and thereafter sent in October 2001 to more than 1,600 university and college presidents. The SASL letter is reproduced on the SASL website [www.umass.edu/per/sasl/] and in Broad (2002, pp. 22427). The list of signatories is also included on the SASL website. There are several points in the SASL letter that are worthy of comment:

- Are colleges and universities making decisions about codes of conduct without adequate consultation?

SASL assertion: "Colleges and universities that have adopted codes of conduct have generally done so after careful consultation with appropriate faculty and/or outsider experts."

Evaluation: The SASL ignores the fact that the adoption of a code of conduct at many institutions was in response to campus sit-ins and protests, and that there was not a broad representation of alternative views and faculty expertise and campus-wide student involvement.

\section{- Worldwide Consultation and Monitoring}

SASL assertion: “... the three organizations (WRC, FLA, and Social Accountability International) bring different strengths to the task of establishing and monitoring effective labor standards worldwide. Ongoing cooperation and competition between these groups should also raise the general performance standard for all three."

Evaluation: As we have noted in our earlier discussion, the primary focus of the WRC on workers rights and collective bargaining and a living wage, the influence of protectionist labor unions, and the adversarial approach to the business community may serve to limit the effectiveness of the WRC.

\section{- Wages, Labor Costs, and Employment Opportunities in the Global Garment Industry}

SASL assertion: "While caution is clearly needed in setting minimum decent standards for workplace conditions, workers rights, and wage levels, there is still no reason to assume that a country or region that sets reasonable standards must experience job losses." 
Evaluation: The fact remains that workers in low-income developing countries are generally being paid wages that are higher than in alternative employment. Mandatory increased wages and more stringent labor standards may improve the position of some workers in the affected industries, but it is almost certain to disadvantage other workers not covered by the mandated changes and may induce firms to seek out lower cost production locations.

In our judgment, many of the points raised in the ACIT letter remain valid and have apparently been accepted in the SASL statement. We remain critical, however, of the SASL statement on the grounds that it: (1) glosses over the ways in which the Anti-sweatshop Campaign led by student activists has intimidated the administrations of many academic institutions; (2) apparently accepts the objectives and operation of the WRC; and (3) downplays the possibly detrimental effects of labor-market interventions in low-income countries. The question remains then as to what the most effective ways may be to address the issues of multinational wages and working conditions in developing countries. One way that we favor and will now consider is the provision of voluntary codes of conduct designed to promote the social accountability of multinationals.

\section{Social Accountability of Multinational Firms}

Having just reviewed the issues involved in the Anti-Sweatshop Campaign and the efforts of activist organizations and academic institutions in the United States to address these issues, we now focus on the options that multinational firms may choose to pursue on matters of their social accountability. In this connection, it might be argued, with externalities aside, that in a competitive environment all that matters to a firm is profit maximization and, to society, the resultant optimal allocation of resources and increased consumer welfare. In this context, competitive firms need not concern themselves with their social accountability, although questions might arise about the distribution of income. But when there are market failures, including the possible exercise of market power by imperfectly competitive firms, there will be grounds for intervention at the firm or industry level, designed to achieve the social optimum.

Market failures aside, it appears to us that the thrust of the Anti-Sweatshop Campaign and other antiglobalization activities represents an effort primarily to alter the distribution of income between rich and poor countries. Under the circumstances, if there is a desire to reduce international income and re- 
lated inequalities, the optimal policy is to provide direct income transfers and technical assistance from the rich to the poor countries. Furthermore, maintaining and extending open markets for the imports from developing countries will be similarly beneficial. It will be suboptimal therefore in terms of resource misallocation if multinational firms are mandated or pressured by interest groups to effect income transfers in the guise of higher wages to workers in developing countries. And more seriously, there is the real possibility that such measures will transfer income not from rich countries to poor countries, but only from workers in poor countries to workers in rich countries.

If the preceding reasoning is accepted, it might be argued that the Anti-Sweatshop Campaign aimed at multinationals is misdirected. ${ }^{22}$ The evidence to be presented in Section IV below generally bears this out. Nonetheless, multinational firms have come under increased scrutiny by activist organizations for their alleged violations of social norms especially in low-wage, labor-intensive industries. It is essential therefore for multinational firms to devise modes of response to allegations of the mistreatment of workers so as to ward off consumer reactions that may be detrimental to their sales and profitability. This is especially the case for firms whose image in the eyes of consumers is derived from a recognized brand name or private label.

As already mentioned, it has become commonplace especially for large multinationals to devise codes of conduct. Thus, as noted in Moran (2002, Ch. 5, p. 5), the Organization for Economic Cooperation and Development (OECD) had 246 corporate codes in its inventory in the year 2000 covering a variety of industries. ${ }^{23}$ This included (p. 7) 37 firms in the textile and apparel industry, 25 of which were U.S. firms. But what should be noted is that a written code of conduct in itself may not be sufficient. What is needed to complement such codes is a monitoring or certification system that is designed to assure code

\footnotetext{
${ }^{22}$ This has led Graham (2000) to entitle his book, Fighting the Wrong Enemy: Antiglobal Activists and Multinational Enterprises.

${ }^{23}$ See also Varley (1998, pp. 505-94) for the texts of a subset of 46 (out of a total of 121) codes of conduct collected for a variety of multinational firms. The Investor Responsibility Research Center (IRRC) has posted profiles of these 46 firms and eight others on its website [www.irrc.org]. We should mention as well UN Secretary General Kofi Annan's Global Compact, which has been signed onto and endorsed by many multinational firms and a number of labor unions and NGOs.
} 
compliance. This is of course what the FLA is intended to do for the apparel industry, and both it and the WRC for university/college suppliers. As we have noted earlier, there are several additional nongovernmental organizations that have been established to carry out monitoring and certification, and there are a number of private monitoring groups as well.

Moran (2002, Ch. 5, p. 9) notes that: "movement toward meeting the prerequisites for credibility and legitimacy [in monitoring and certification] has not been smooth." Some of the issues that have proven troublesome include: circumscribing the availability of information on plant locations on confidentiality grounds; the use of business and auditing firms to conduct inspections; public disclosure of alleged code violations and efforts at remediation; and comprehensiveness of scheduling of monitoring and follow up. ${ }^{24}$ It is no doubt too much to expect that a system of monitoring and compliance will be perfect. Nonetheless, as Moran (p. 12) has concluded: "There has ... been considerable movement, albeit contentious movement, toward meeting the conditions needed to create a credible 'voluntary' system for certifying plants that comply with good worker standards and identifying plants that do not."

If this judgment is correct, it suggests that many multinational firms have found it in their interests to devote resources as a kind of insurance against the possibility of unfavorable publicity regarding their operations that could prove damaging to them in the eyes of consumers and thereby reduce their sales and profitability. ${ }^{25}$ By the same token and apart from the issues of code monitoring and compliance, it should be recognized, as Moran (2002) has stressed in his study Beyond Sweatshops, that the improve-

\footnotetext{
${ }^{24}$ See Varley (1998, esp. Ch. 11 and 12) for a discussion entitled "Corporations Grapple with Codes of Conduct" and "The Compliance Conundrum."

${ }^{25}$ Bhagwati (2001) makes the case more strongly in arguing that: “... the truly, indeed the only, compelling reason for corporations to assume social responsibility is that it is the right thing to do. For, in so doing, they will accelerate the social good that their economic activities promote, and for which there is now much evidence." Ruggie (2002), who served as an advisor to UN Secretary-General Kofi Annan in helping to develop the Global Compact, notes that the Global Compact is based on a learning approach to induce corporate change rather than a regulatory arrangement involving a legally binding code of conduct with explicit performance criteria and independent monitoring of company compliance. Ruggie notes further that the Global Compact comprises a network form of organization that comprises the UN, business, labor, and civil society organizations. The hope is that the Global Compact will assist companies in internalizing the relevant principles of social policy embodied in the Global Compact and thereby induce the companies to shape their business practices accordingly. Whether or not this objective can be attained, Ruggie concludes, will depend on the viability of the inter-organizational networks being developed.
} 
ment of wages and working conditions is an ongoing process as economies evolve, bringing about endogenous changes in the structure and composition of output and conditions of employment, including a movement towards more technologically advanced industries. For this to happen, as already mentioned, it is necessary for governments to adopt domestic policies that will enhance economic efficiency and welfare and thereby provide the basis for improvements in workers' skills and the conditions of work.

\section{The Role of the International Labor Organization (ILO) and the World Trade Organization (WTO)}

We have focused thus far on the efforts and issues involving the design of codes of conduct, monitoring, and compliance applicable to multinational firm operations in these countries. These various issues have also been addressed at the multilateral level, and there has been a continuing debate on whether or not, and how, to deal with trade and labor standards in the ILO and WTO.

The crux of the argument is that the ILO is an international organization that was established around 80 years ago for the purpose of improving labor conditions in its member countries. The ILO mandate is carried out by specifying conventions covering a variety of labor issues and conditions of work to which member countries agree to adhere. These conventions include the so-called core labor standards, which cover forced labor, freedom of association, the right of collective bargaining, equal pay for men and women, discrimination in the workplace, the minimum age of employment, and ban on the most egregious types of child labor. These core and other labor standards have been incorporated in various forms into most of the codes of conduct of NGOs, colleges and universities, and multinational firms. The modus operandi of the ILO is to monitor member-country compliance with the various conventions, call attention to departures from the conventions, and provide technical and financial assistance for developing countries to help them upgrade their labor standards. The ILO thus functions as a clearing house to provide information on labor issues and as a facilitator to improve labor conditions. It carries out its mandate without the use of or threat of sanctions against non-complying member countries.

The WTO is an international organization whose main purpose is to design and implement rules governing the conduct of international trade among its member countries. In contrast to the ILO, the 
WTO does have sanctioning authority that permits member countries to impose trade restrictions in cases in which trading partners are found via the WTO dispute settlement process to be in violation of particular WTO rules. The trade sanctions can remain in place until such time as the violation is corrected by a change in policy. As tariffs have been increasingly reduced in periodic multilateral trade negotiations, there have been efforts to probe more deeply into the domestic nontariff regulatory policies of member countries that may impede trade. It is in this context that proposals have been made to link labor standards and trade, on the grounds that countries with allegedly low labor standards may have an unfair advantage in their trade that is detrimental to their trading partners. In Brown, Deardorff, and Stern (2002), we have explored the pros and cons of linking trade and labor standards in the WTO. In the final analysis, we oppose such linkage on the grounds that it may be subject to capture by protectionist interests in the developed countries and be detrimental therefore to the trade and welfare of developing countries. In our judgment, issues of labor standards should continue to be the responsibility of the ILO.

This concern about protectionist influence relates as well to the Anti-Sweatshop Campaign discussed earlier, especially in view of the support that UNITE and other organizations with a protectionist orientation have provided to activist organizations such as the WRC. Of course, there are many activist organizations that are motivated by concerns over human rights and international inequalities in the distribution of income. In our view, while these concerns are commendable, they are for the most part misdirected against the operations of multinational firms. There is a real danger therefore that wellintentioned efforts to raise the wages and working conditions of workers in developing countries may work to the detriment of these workers and their families. Instead of focusing on codes of conduct, monitoring, and compliance, society would be better served if efforts were directed by activist groups and universities/colleges to the reduction or removal of existing trade barriers and domestic impediments to economic efficiency in both developed and developing countries. 


\section{Conceptual Considerations}

The preceding discussion was designed to focus on the sweatshop and related issues as a specific example of interest to many concerned about the impact of multinational firms on wages and working conditions in developing countries. With this in mind, we now turn our attention more broadly to a review of what economic theory has to say about the effects of FDI and multinational firms on wages and working conditions in host countries. We begin with a brief discussion of the motivations for FDI and multinational firm activity. One lesson of that is that multinationals exist for a variety of reasons and perform a variety of functions, so that we cannot identify them with any single activity whose effects we should explore. Rather, we need to consider them in several roles, each of which may have different implications for wages and working conditions.

We look broadly at four such roles. The first is as a conveyer of additional capital to the host country, either as an addition of the world's capital stock or in place of capital that would otherwise be in the source country. For this purpose we address the question in the context of the general equilibrium models with perfect competition that are familiar in international trade theory. Second we consider the possibility that FDI carries with it, instead of or in addition to capital, technologies that may be superior to those previously available, technologies that may also "spill over" to domestic workers and/or firms in the host country. Again, FDI as a source of improved technology can be analyzed in the context of perfectly competitive general equilibrium trade models. Third, we acknowledge that, even with unchanged capital and technology, multinational production may involve different sets of production activities than simpler national firms, and we look at how the choice of activities may matter for labor markets. This may happen, for example, within multinationals that use their parent-firm location to provide headquarters support for activities in subsidiaries abroad, or more generally it may involve production processes that are fragmented across countries, even to be done in different unaffiliated firms through subcontracting. Fourth and finally, we note that, because of their size, multinationals may have the power to set prices and/or wages to a degree that perfectly competitive firms could not. We examine several ways that 
their price-setting behavior could matter for wages, including monopsony pricing of labor, efficiency wages, and rent sharing.

Throughout this section we focus for convenience only on wages, rather than explicitly considering the full package of wages, other compensation, and the hours and working conditions that firms ask of and provide to their workers. In practice, of course, all of these are determined together, either in the competitive interactions of firms and workers, or in negotiation between them. In general, therefore, when we say that an event such as FDI raises or lowers wages, one should think here of the whole package of wages and working conditions as improving or worsening to an extent that is determined by these interactions. $^{26}$

\section{Motivations for FDI}

FDI consists of the acquisition of physical capital in another, or "host," country, usually in the form of a production facility or a retail establishment owned at least in part by a parent firm in the home, or "source," country. ${ }^{27}$ When done among developed countries, FDI often takes the form of acquisition of an existing facility, but most FDI into developing countries is "greenfield" investment - that is, newly constructed establishments - which therefore add to the physical capital of the host country. ${ }^{28}$ Strictly speaking, such capital need not be financed from the home country, and it therefore need not in any sense be a movement of capital from the home country to the host country, although in practice it is often interpreted that way. For our purpose, however, of examining the effects of FDI on the host country, this distinction is not important. What matters is primarily the fact of, and the nature of, the addition to capital in the host country.

\footnotetext{
${ }_{27}^{26}$ Lim (2001, p. 41) notes that "higher wages are usually correlated with better labor standards."

${ }^{27}$ It should be noted that FDI may span a variety of industries, including extractive, manufacturing, and service industries. The literature tends to focus especially on FDI in manufacturing, but our discussion is intended to encompass FDI covering the range of different industries. According to Kucera (2001, p. 17): "As of 1997, 50.1 percent of FDI flows into LDCs went to manufacturing (down from 66.8 percent in 1988), compared to 41.3 percent to services... and 4.6 percent to the primary sector." The remaining FDI was "unspecified."

${ }^{28}$ See Graham (2000, p. 85). Krucera (2001, p. 4) notes that: "For less developed countries, the value of M\&As (mergers and acquisitions) in relation to total FDI inflows increased from about 15 to 30 percent from 1993 to $1999 . . . "$
} 
FDI also often carries with it a technology that may not have been previously available in the host country. That, as well as the additional possibility that such technology may spread to workers and firms outside the foreign-owned establishment, is something we will consider in a later subsection. To start, we will focus only on the role played in the host country by the additional capital.

To some extent, that role may depend on the motivation for the FDI itself. Broadly speaking, there are two types of FDI: that intended to serve the host-country market and that intended to produce for export. ${ }^{29}$ Obviously, there exists some FDI that serves both purposes, but if so, one purpose is usually dominant and the other incidental. The distinction can be important because the firms that engage in FDI usually have alternative means available for achieving either of these objectives, and their choice of FDI is an indication of market conditions that favor FDI over these other means.

In the case of serving the host-country market, the alternatives are to export the product from the home country or, especially in the case of services, to franchise or otherwise license its production by a local firm in the host country. Since the firm's competitive advantage originated with production in its home country, the choice of FDI instead of these alternatives indicates that there must be extra costs associated with them. For exports, these extra costs include transport costs, tariffs, and other trade barriers; for licensing, they include costs of controlling quality or protecting technology. In both cases, FDI is likely to be a higher-cost method of producing the product than the alternative, chosen only because these other costs are even higher. This second-best nature of FDI in such cases may undermine the benefits that one would otherwise expect from freely functioning markets. For example, "tariff-jumping" FDI may involve production that is so inefficient that it lowers the welfare of the host country. Likewise, concerns about control of technology may induce firms to use only outmoded machines for serving a host-country market.

\footnotetext{
${ }^{29}$ These types of FDI are also frequently referred to, respectively, as "horizontal" and "vertical" FDI, as noted in Krucera (2001, pp. 4-5).

${ }^{30}$ The points made here and in the next two paragraphs draw on Moran (2002).
} 
In the case of FDI for export, the alternatives are, first, not to involve the host country at all, producing either at home or in a third country, and second, again, the possibility of licensing production to a host-country firm. Here there is no reason to produce in the host country at all unless it can be done for lower cost (or higher quality), so the presumption is that the host country offers an advantage in the form of cheaper and/or higher quality inputs, such as labor or some natural resource. The decision to own the facility rather than to license it could, again, reflect distrust of local firms that outweighs the cost advantage that local firms presumably have due to their familiarity with host-country conditions. However, it may be more likely, since the local market is now less important, that the firm can achieve cost or quality advantages itself by using its own personnel. The result here is a presumption that FDI for export will reduce the cost of providing the product to the home or to the world market, and we would expect this cost reduction to be beneficial, at least from a global perspective.

What is it that allows a multinational to achieve such a cost reduction that a local firm, unaffiliated with the multinational, could not? The answer may only be that the multinational has better access to capital, which is why we start by considering the effects of capital flows on wages. Or the multinational may have a technology that is not available in the developing country, or even outside the multinational itself, as we examine second. But a third possibility is that the multinational produces an input in one country, perhaps the source country location of the parent firm, that contributes to the productivity of other activities that it performs in the host country. One or both of these activities may also have the nature of a public good, expanding productivity of multiple affiliates in multiple countries, but that is not essential for our concern here with effects on host-country labor markets. What is important is that the multinational provides the motivation for locating a fragment of its production activity in the source country, an activity that without the multinational would not be viable. This fragmentation is the third source of cost reduction that we examine below. 


\section{Effects of International Capital Flows}

The simplest story one can tell about FDI is in a one-sector model. Suppose that all countries produce the same good, using inputs of capital and labor in a neoclassical, constant-returns-to-scale, production function: $X=F(K, L)$, where $X$ is output and $K$ and $L$ are factor inputs of capital and labor respectively. FDI from abroad then increases a host country's capital stock and raises its output. With competitive factor markets paying factors the value of their marginal products, the increased capital stock will raise the marginal product of labor and thus its wage. There is no possibility here of FDI hurting the host country's labor, and if the amount of FDI is large enough to matter at all, it will surely help it. Of course, the flip side of this is in the source country where, if the FDI entails a drop in the capital stock there, the opposite occurs. But that is not our concern here.

One need not go far to find a different theoretical answer, however. In standard Heckscher-Ohlin (HO) trade theory, with two sectors producing two goods in each of two countries, the factor price equalization (FPE) theorem tells us that an increase in the capital stock of a country will leave both factor prices unchanged in either of two circumstances. ${ }^{31}$ First, if the host country is small so that any change in its outputs will not affect world prices, then an increase in its capital stock, whatever its source, will leave its factor prices unchanged as long as the country continues to produce both goods. And second, even if the host country is large, if the increase in its capital stock matches an equal decline in the capital of another country, as it would if FDI actually moves capital from place to place, then if that other country also produces both goods both before and after the change, factor prices will again stay the same.

Considering the obvious importance of international trade in the world today, one might think that this two-sector HO model ought easily to be preferred over the one-sector model and that we should forget about FDI affecting wages. But the case just considered is actually very special, and there are many other possibilities within the general HO framework that do not yield this result.

\footnotetext{
${ }^{31}$ It is this implication of the FPE theorem that causes Leamer and Levinsohn (1995) to rename it the factor-priceinsensitivity theorem.
} 
First, the simple specific factors model with mobile labor and two kinds of immobile capital (which can be thought of as a three-factor, two-good case of the general HO model) has the property that an increase in either capital stock raises the wage even in a small country. Second, with specialization, the HO model behaves much more like the one-sector model, with each country producing a single, albeit different, good. Third, without complete specialization but with multiple "cones of diversification,", a movement of capital from a capital-abundant to a labor abundant cone will cause prices of goods to change in a way that causes internationally unequal factor prices to move closer together. In this last case, far different on its face from the one-sector model, FDI again causes the wage to rise in the host country and to fall in the source country, with opposite changes in returns to capital.

Perhaps the richest variant of the HO model for use in describing developing countries is a twofactor (capital and labor) model with many cones of diversification. In this model, FDI that raises the capital stock of an initially poor, small country sufficiently will cause it to grow from cone to cone, with the wage remaining constant as it advances within a cone, but then rising as it moves up to the next cone. This sort of progress, which has been explored theoretically by Krueger (1977) and Deardorff (2000) and has been documented empirically by Moran (2002), may offer the best hope for developing countries to escape poverty if they can accumulate capital (or skill, although this is outside these simple models), either on their own or with the help of FDI.

So far we have considered models with only two factors, capital and labor. Equally important is the distinction between skilled and unskilled labor, but to address this along with capital flows requires allowing for three factors of production. This opens up more possibilities than we can consider here, and we therefore look only at a single case, but it is one that seems particularly appropriate for today's world.

\footnotetext{
${ }^{32}$ This refers to the property of HO models with more goods than factors that equilibria can involve FPE for groups of countries whose factor endowments lie within a cone-shaped subset of factor space. If there is only one such cone, then all countries either completely specialize (and are thus outside the cone) or share common factor prices. If there are multiple cones, then countries whose factor endowments are within the same cone (and thus are in that sense similar in their factor endowments) diversify and share a common set of factor prices, but they have different factor prices than countries in another cone. A popular model of trade between developed and developing countries has two such cones, with capital-abundant developed countries in one and capital-scarce developing countries in the other.
} 
The model is another variant of the HO model, this one introduced by Feenstra and Hanson (FH) (1996). They assumed a continuum of goods, each produced with capital and a fixed-coefficient aggregate of skilled and unskilled labor. The skill/unskill intensities varied along the continuum, while the shares of capital versus aggregate labor did not. In their equilibrium, factor endowments differed between their two countries, North and South, sufficiently that factor prices were unequal and each country produced a different range of goods - i.e., they were in different cones. In particular, FH assumed that the return to capital was higher in South than in North, and that the ratio of the skilled wage to the unskilled wage was also higher in South than in North. ${ }^{33}$

FH used this model to derive a result that is very relevant here. When capital moves from North to South, it expands the range of goods that can be produced in South and contracts that range in North. The goods whose production location moves are the least skill-intensive previously produced in North, and they become the most skill-intensive now produced in South. As a result, the average skill intensity of production rises in both countries. This also raises the relative demand for skilled labor in both, causing the skilled wage to rise in both places and the unskilled wage to fall. This is the first sign we get, in theory, of FDI causing a fall in any wage in the host country. It does so because, rather than moving into producing the goods that use the cheapest factor in that less developed country - unskilled labor - FDI instead expands production of relatively skill-intensive products there. As we will see in our look at the empirical evidence below, this is exactly what a great deal of FDI into developing countries actually does. Why does it do this? In the FH model it happens because production of the least skill-intensive goods is already, in the initial equilibrium, being done exclusively in the South. In those industries, there is nothing to move. So if capital is going to move to South at all, in order to take advantage of the higher return to capital there, it must produce something else, and more skill-intensive goods are all that are available.

This is an interesting result that strikes us as important, and we will hark back to it frequently later in the paper. However, there is a qualification that Feenstra and Hanson do not mention. Theirs is a

\footnotetext{
${ }^{33}$ This is nicely consistent with having both wages realistically lower in South than in North, although FH also allowed international differences in technology that could lead to this result.
} 
two-country model, with both countries of significant size. We are often concerned, not with a massive flow of capital from the developed to the developing world, but rather with flows into particular developing countries that might better be viewed as small. What effects would FDI have into a small country that is embedded in what is otherwise the FH framework? The answer is that it would not affect relative wages in the small country at all.

The reason is essentially that a small developing country in the FH framework is within the cone of diversification of the South, and its factor prices are constrained by those of the South as well. This is not to say that factor prices will be equalized. The small country will be able to specialize completely in the only one of the continuum of goods that fully employs its skilled and unskilled labor, and thus the FPE theorem does not apply. However, to keep producers from shifting to any other good in the continuum within the cone, the ratio of the skilled wage to the unskilled wage must remain the same as in all of the other countries of the larger South. ${ }^{34}$ As a result, as FDI expands the capital stock of the small country, wages of both skilled and unskilled labor rise in the same proportion, while the return to capital falls.

All of the theoretical results discussed so far are collected in Table 1, which shows the direction of change in the real wage of labor in the host country due to capital-inflow FDI. Each of the models considered is identified by the number of sectors and factors that it assumes. Also indicated is whether the host country is diversified or specialized into production of a single good and whether, where relevant, the world equilibrium has two cones of diversification. Results are reported for both the case of a small country, which takes prices as given from a much larger world economy of the sort indicated, and for a two-country model. In the latter case, the FDI is assumed to take the form of an increase in the capital stock in the host country together with an equal decline in the capital of the source country.

\footnotetext{
${ }^{34}$ This can be seen in the FH model by differentiating the (log of the) cost function with respect to the index of the good, $z$ in the FH notation. This derivative depends on the factor prices only through the ratio of the two wages, $q_{i} / w_{i}$. If a small country had a wage ratio differing from that of the larger South at the $z$ that can fully employ its two kinds of labor, then its cost function would cut South's from above or below, and firms would seek to produce only goods of higher or lower $z$. Labor markets would not both clear.
} 
The results, clearly, are somewhat varied, in that there are several cases where wages do not change and even one where a particular wage - that of unskilled labor - falls. However, most of the cases show labor earning a higher wage as a result of an inflow of FDI, and we regard this as the normal case, in the absence of knowledge that circumstances are otherwise.

\section{Effects of Technology Flows}

It is arguably the case that multinationals who engage in FDI possess technologies that others do not, particularly other firms in their host countries. They must, after all, have some sort of advantage in order to overcome the disadvantage of operating in an unfamiliar environment. And if this is the case, then FDI is not fully captured by the simple inflow of capital considered above. Indeed, some FDI may actually involve no addition to a host country's capital stock at all, if the capital already exists and is simply acquired by the multinational through merger or acquisition. In that case, FDI may consist purely of the introduction of an improved technology into the host country.

This is not necessarily technology transfer, if the secrets of the technology remain with the acquiring firm and its source-country personnel. But the technology will still be applied to factors in the host country, and it will increase the output that they produce, even if the advantage would be lost if the firm pulled out. Thus we can model this as an improvement in technology and ask its effects. If technology transfer does take place, willingly on the part of the firm or otherwise, then these effects will be just that much larger and longer lasting.

Graham (2000, Appendix A) argues that an improvement in technology must raise wages. After all, he says, technology raises productivity, and workers are paid their marginal product, which will be larger as a result of the improved technology. However, this ignores the interaction of supply and demand. A competitive industry with an improved technology will expand output and employment until the value of labor's marginal product equals its wage, but this could happen in several ways: by a fall in the

\footnotetext{
${ }^{35}$ It is not inevitable that even some labor must gain. For example, in a one-sector model with three factors - labor, capital, and land - if capital is a complement for land and a substitute for labor, a rise in the capital stock could reduce the wage of all labor.
} 
price of the good, as output expands relative to demand; by a fall in the marginal product of labor, as employment expands relative to other factors such as capital; and by a rise in the wage, as workers are induced to leave other industries or to give up leisure. Only the third of these mechanisms entails an increase in the wage, and it will not happen at all in some contexts, such as that of FPE. Thus there really is no assurance that an improvement in technology due to FDI will raise the host country wage at all. It will depend on the circumstances, just as did the effect of a capital inflow above.

Consider first a single multinational firm that brings an improved technology into a host country. Will it pay a higher wage than what prevails in the local market? It may, for any of several reasons that we will discuss below, but the increased marginal product of labor is not one of those reasons. If the marginal revenue product of labor is initially higher than the prevailing wage, then the firm will expand its use of labor to the point where this would not be true for an additional unit of labor. But even then it has no reason, on account of the technology alone, to pay more than the market wage. This argument applies as well to larger numbers of firms as long as they do not alter the technology of all firms operating in the sector - a case we consider next. Of course, with more firms expanding employment, the effect on the market wage itself may become significant, the wage rising as labor is pulled up its supply curve, but if this happens it is due to the expanded demand for labor, independently of whether its cause was an improvement in technology.

Suppose next that FDI brings to a host country an improved technology for a whole sector of the economy, either because multinationals themselves take over the whole sector or because spillovers of the technology raise productivity in local firms as well. Like the case of an increased capital stock above, several possibilities arise depending on country size and patterns of specialization. In the simplest case of a one-sector economy, the effect of technology depends on its factor bias. Hicks neutral improvement will raise all factor prices in the same proportion, while improvement that is biased toward use of one factor or another will raise one factor price more than another and may even cause one factor price to fall. Thus it is possible, if the new technology is biased strongly enough away from using labor, for it to reduce the wage, although this seems an unlikely outcome. 
With multiple sectors, on the other hand, as has been discussed at length in the "trade and wages" literature, the effects of a technological improvement on wages depend on the relative factor intensity of

the sector in which it occurs. ${ }^{36}$ In a small, two-sector, diversified economy, for example, improvement in the capital-intensive sector will lower the wage, while improvement in the labor-intensive sector will raise it. With more sectors and multiple cones, it is again the factor intensity of the sector where technological change takes place that matters for factor prices, though here it is factor intensity relative to other sectors in the same cone, not relative to all sectors. All of these theoretical results are summarized in Table 2.

\section{Fragmentation}

So far we have treated multinationals as providing capital and/or technology to developing countries and then using it within the same industries that already exist, either there or in the source countries. In fact, an increasing amount of multinational firm activity involves changes in the organization of production so that portions of a previously integrated activity can be done elsewhere. This phenomenon, which has gone under many different names, we will here call "fragmentation." It may take the form of a sourcecountry firm building a subsidiary abroad to perform some of the functions that it once did at home, such as making particular parts for its product or completing particular steps in its production process. Or it may take the form of subcontracting such activities to local firms in the host country, to which it provides detailed specifications and even fragments of its technology. In both cases, this activity may be included in what is often called "outsourcing." And in both cases too, it may or may not be accompanied by an increase in the host-country capital stock or by an improvement in technology. What is distinctive about fragmentation is that a portion of the activity that was previously done in the source country now becomes possible to do in the host country instead. Fragmentation may not require any expansion of the multinational firm's direct operations, and it therefore may not be recorded as FDI, but it is nonetheless the existence of the multinational firm that makes it possible.

\footnotetext{
${ }^{36}$ See Krugman (2000) and the references cited therein.
} 
By the same token, it is often the potential for fragmentation that makes a multinational firm possible, or at least provides the economies that make multinational firms more efficient than national ones. It is not unusual for some fragments of a firm's activities to serve the needs of multiple other fragments, creating a form of economies of scale. For example, research and development need only be done once for all of the subsidiaries of a multinational firm. Indeed, it is this feature of many multinationals that Markusen (1984) and Helpman (1984) used as the basis for their seminal models of multinationals. ${ }^{37}$

For our purposes here, it is what a multinational does and not so much why it does it that is important. Once a fragment of production is located in a host country, it matters little for that country's labor market whether the it is there because of multiplant economies or for some other reason.

Fragmentation is both motivated and constrained by the same things that matter for international trade in general. A fragment of a production process will be moved abroad only if it can be done there more cheaply, which means that fragmentation is responsive to the same determinants of comparative advantage as any other trade. In particular, it is likely to occur only if factor prices differ across countries. Even then, it will not occur if the extra costs that are associated with fragmentation outweigh the gain from lower cost of the activity itself. These extra costs may include transportation, communication, and other costs needed to coordinate the activity with what is still being done in the home country.

Both the causes and the effects of fragmentation in general equilibrium have been examined by Deardorff (2001a,b), among others. There is some tendency for fragmentation, like trade more generally, to cause internationally unequal factor prices to move closer together. However, no general conclusion in this regard seems to be possible, and the effects of any particular instance of fragmentation may do this, or its opposite, depending on the factor intensities of the fragments.

Thus, to take a not implausible example similar to the movement of capital studied by Feenstra and Hanson (1996), suppose that an industry has previously functioned entirely within a developed country where the relative wage of skilled labor is relatively low due to its abundance. Now it becomes possi-

\footnotetext{
${ }^{37}$ See also references cited in Carr et al. (2001) for more extensive modeling of multinational firms based on this assumption.
} 
ble to split off a portion of that production process, one that is less skill-intensive than the industry as a whole. In the absence of factor price equalization, this fragment of production will cost less in the developing country, to which it will now move if the cost savings more than cover any increased cost of transportation, communication, etc. How it will affect factor prices there, however, depends on just how unskilled-labor-intensive it is. If it is more skill-intensive than the average of existing production there - as it may well be, since all activities in the developing country are less skill intensive that those at home then it will put upward pressure on the relative wage of skilled labor in the developing country. Since this relative wage was already higher than in the developed country, this particular example of fragmentation may be moving the two countries' factor prices further apart. ${ }^{38}$ Of course, this is just one example, and fragmentation could equally well cause an even less skill-intensive fragment to be outsourced, in which case the effect on factor prices would be the reverse. The lesson is only that anything can happen, depending on factor intensities of fragments relative to factor endowments of the country. And there seems to be no reason to expect any one pattern of these factor intensities more than any other.

\section{Imperfect Competition}

We have assumed so far that firms engaged in FDI are perfectly competitive in all markets. Since these are multinational firms, large almost by definition, many would undoubtedly question this assumption. In fact we believe that the assumption is not that bad in many cases, since even large, multinational firms face considerable competition, both from others like themselves and from smaller actual and potential entrants. But it is surely worth asking whether market power can cause a firm engaging in FDI to pay wages higher or lower than we would expect from perfect competitors.

Imperfect competition can take many forms, of course, and there probably exist market structures that will yield just about any theoretical result that one wants to get. We won't play that game, but will merely assume that the firms we consider have some market power. That is, they face market prices that

\footnotetext{
${ }^{38}$ What happens to factor prices in the other country depends on the factor intensities of the industry before and after fragmentation occurs, relative to factor endowments there. See Deardorff (2001a).
} 
depend on the quantities they buy or sell, and we ask how this matters. Formally, our firms are now monopolists or monopsonists, or perhaps monopolistic competitors without our considering effects on entry.

The most obvious place for market power to matter for wages is in the labor market itself. Suppose that FDI creates a monopsonist buyer of labor in the host country. If it faces an upward-sloping supply curve of labor, such a firm will employ less labor and pay lower wages than it would under perfect competition, since it recognizes that the wage needed to elicit an additional unit of labor must be paid to all employees. Does this mean that such FDI actually lowers wages? Probably not, since the labor supply curve reflects whatever residual options the workers have, such as subsistence farming, and without the FDI the wage from these other sources would be no better, and perhaps even lower. However, it is not difficult to construct a scenario in which monopsonist FDI lowers wages. Suppose that prior to the FDI labor was employed by a competitive local industry with a more primitive and therefore lowproductivity technology than the multinational's. If the FDI, due to its superior technology, displaces those local firms, and if the resulting monopsonist multinational pays less than workers' (now higher) marginal product because of its market power, then wages might go down. This is only a possibility, of course; wages might just as well rise. It depends on the parameters of the problem.

Monopsony in labor markets is possible, and historically it may even have been quite common. But today's multinationals often tend to be attracted especially to urban areas where they must compete in labor markets with many other firms, so monopsony today is arguably less of a concern.

More obviously, many multinationals appear to have market power in output markets. One thinks immediately of prominent brands like Nike and McDonalds, but they are hardly alone. In fact, a great deal of production by and for multinationals is of inputs that are produced by many competing firms, so we would not regard market power in output markets as the norm. But it surely exists.

Suppose, then, that FDI is undertaken by a multinational firm that is a monopoly as a seller of its product, either to the world market or to the local, host-country market. How will this firm's behavior differ from that of a perfect competitor? The answer, of course, is that it will produce a smaller quantity and charge a higher price than a perfect competitor, meaning that its price will be above its marginal cost 
of production. On its face, this says nothing about the wages this firm will pay, and in fact, since we have now assumed no market power in the labor market, it will simply pay the market wage.

What is notable, however, is that, unlike a perfect competitor, this firm does not pay a wage that is equal to the value of its labor's marginal product. Instead, its wage is equal to its marginal-revenue product, taking into account that the output of an additional worker would have to be sold on the product market by charging a lower price on all inframarginal units. Put simply, because the monopolist charges a monopoly price for its product, the value of what a worker produces at the margin, valued at the monopoly price, is higher than the wage. Of course there are many reasons why the market price of a Nike shoe is much higher than the cost of the labor that produces it, including payments to many other inputs in both production and distribution, but the fact that the shoe is sold for a monopoly price contributes to this. This does not mean that Nike's market power in the shoe market has permitted it to pay a lower wage to labor. It has not. But it does contribute to the perception that Nike could afford to pay its workers more. And indeed it could, if it were somehow willing or compelled to accept a smaller monopoly profit.

Under the heading of imperfect competition, we should also consider the possibility that labor markets may depart from the perfectly competitive norm on the supply side, rather than (or as well as) on the demand side. That is, labor markets may be unionized, or they might have the potential for being unionized if multinational firms were not present. Here is perhaps the clearest case we can see for FDI and multinational firms to reduce wages, since any market power that workers may be able to acquire by organizing is bound to be diminished if the firms that they bargain with have the option, as multinationals, of producing elsewhere. Unions are in fact notoriously weak in developing countries, and they were already weak, in most cases, before the arrival of multinational firms. But as these countries' incomes rise, it is plausible that unions would gain in strength, and that they would gain faster, other things equal, if multinational firms were not present. Other things would not be equal, however, and without FDI the growth of income that permits the growth of unions might not occur.

The presence of unions matters in another way, however, when it is combined with productmarket power by the employers. Bargaining over wages will result in workers sharing a part of the firm's 
monopoly profits, as discussed and documented by Katz and Summers (1989). ${ }^{39}$ If a multinational has greater profit than a domestic employer, then it may well pay higher wages for this reason, offsetting the effects of its greater bargaining power.

\section{Payment of Above-Market Wages}

Except for this last-mentioned possibility of bilateral monopoly involving a multinational and a union, the theories we have considered so far do not allow for or explain a phenomenon that we will see below to be quite common: that multinational firms pay higher wages than do local, host-country firms. To a partial extent, this phenomenon is an artifact of the data. If multinational firms draw on different parts of the labor market than average local firms, then they may pay higher wages just because on average they require different sorts of workers, in terms of education, skill, or location. However, the evidence below will show that multinationals continue to pay higher wages than local firms even after accounting for these effects and several others. Standard competitive models, and even most familiar models of imperfect competition, do not explain this. Nor does the suggestion, often made, that workers are somehow more productive in multinational firms, since as we have seen in looking at the role of technology, this does not provide a valid theoretical reason for firms to pay higher wages than are needed to attract their workers.

Relatively standard explanations for this behavior do exist, however, in the macroeconomic literature on "efficiency wages" that was developed to explain both downward wage rigidity and unemployment. There are several versions of this theory, summarized for example in Yellen (1984), all of them providing reasons why workers will become more productive or efficient as a result of being paid more. That is, in efficiency wage theory, the high wage is not the result of higher productivity, but its cause.

The simplest and apparently oldest version of efficiency wage theory applies best to developing countries, where market wages may be insufficient to sustain workers' health. Firms may therefore pay higher than the market wage in order to improve the health of their workers and thus their productivity.

\footnotetext{
${ }^{39}$ See also Budd et al. (2002) and references cited therein.
} 
Other versions of the theory depend on somewhat more complex modeling of interactions between firms and workers. They can be summarized by saying that firms pay higher than market wages in order to: (1) reduce shirking (or elicit greater effort); (2) reduce turnover and the costs of retraining; (3) attract and retain the most able and productive workers from a heterogeneous workforce; and (4) improve worker morale in a context where social pressures can make workers more productive.

An alternative explanation for payment of above-market wages is possible in precisely the context that anti-globalization protest is serving to create. In the preceding section, we discussed the AntiSweatshop Campaign and other public pressures that have been brought to bear on multinationals for allegedly mistreating their workers. This pressure may well be creating a reluctance on the part of at least the most visible multinationals to be seen providing wages and working conditions that could become a source of embarrassment and lost sales, even when these are at levels generally prevailing in local markets. In response to that pressure, then, they may pay above equilibrium wages even when they do not expect this to improve the productivity of their workers. It is unlikely that much of the empirical evidence for high wages by multinationals could be due to this, since the data mostly predate the antiglobalization movement. However, it is plausible that multinationals may currently be responding to that pressure, and that future studies of wages paid by multinationals will reflect that.

In all of these stories, it is clear that the workers who receive the above-market wages are better off than those who do not (although in the case of efficiency wages this gain may be partially offset by any extra effort that they provide in return). And if FDI expands employment in firms that pay abovemarket wages, a larger number of workers will enjoy these benefits. However, it is not necessarily clear that all members of the country's labor force are, on average, better off. The efficiency wage models, in particular, were developed in part to help explain unemployment. Indeed it is likely that above-market wages, whatever their cause, will be accompanied by increased unemployment of workers who are waiting and hoping to get these desirable jobs.

Years ago, Harris and Todaro (1970) proposed a model in which a given above-equilibrium wage was paid in the urban sector of an economy, inducing migration from the rural sector and urban unem- 
ployment to the point that the expected wage of these migrants equaled the lower rural wage. This expected wage included not only the high wage of employed workers, weighted by the probability of employment, but also the zero wage of the unemployed weighted by the probability of not finding a job. This same model could be applied within an urban sector, where certain firms pay higher than market wages for any of the reasons we have discussed. They too will attract a larger pool of workers than they can employ, workers who will accept either unemployment or lower-than-market wages in return for the chance of eventually getting one of these high paid jobs. In equilibrium workers as a group, both employed and unemployed, are not better off than those who continue to work elsewhere in the economy for the market wage. And of course there is the additional unhappy consequence of greater inequality among workers, some of whom have these high paying jobs and others of whom do not.

In this framework, the market offers potential workers the same expected wage that they can earn somewhere else, far from the high-wage sector. Therefore, simply adding more firms that pay abovemarket wages may not change that equilibrium expected wage. Instead, although the market looks very different from the usual competitive model, the underlying forces that will change average wages economy-wide will be the same forces of supply and demand that we have discussed earlier.

In the case of efficiency wages, the firms get something in return for their higher wages that they could not necessarily get elsewhere - higher productivity from their employees - and that together with the low market wage, to which the wage premium is added, is what attracts them to produce in these countries in the first place. But when above-market wages are being paid for other reasons, such as pressures from NGOs, enforcement of minimum wage laws, or even fear of government sanctions, the benefit of avoiding public censure may be obtained as well by producing somewhere else, rather than by paying higher wages in poor countries. Whatever may be the level of wages and working conditions that will satisfy a critical public, firms may choose to produce in countries where that level is already the equilibrium due to workers' higher productivity. If so, then an additional effect of the pressure to pay higher wages will be a loss of employment in low-wage countries. 
Leamer (1999) has provided an account of wage differentials that differs somewhat from the efficiency wage story, although it too rests on the degree of effort exerted by workers. His model has the advantage of being amenable to general equilibrium analysis. In his model, "effort" determines total factor productivity in a two-sector, two-factor context that is otherwise that of the HO model. Since the return to effort is, in effect, higher in the more capital-intensive sector, equilibrium has that sector paying higher wages and requiring greater effort from its workers than the labor-intensive sector. This model has a long list of striking implications, only one of which need concern us here.

In Leamer's effort model, an increase in a country's capital stock, which could (but need not) be due to FDI, has remarkably different implications in closed and open economies. In a closed economy, increased capital lowers the relative price of the capital-intensive good. This lowers the return to effort and leads to a reduction in effort levels in both sectors. In a small open economy, on the other hand, increased capital may, in one type of equilibrium, leave factor prices and effort levels unchanged, through a variant of FPE. But, in another type of equilibrium, it may lead instead to new production of capitalintensive goods, thus creating higher-effort, higher-wage jobs.

All of the cases we have considered in this theoretical overview - capital flow, technology flow, and fragmentation - have failed to yield unambiguous conclusions about the effects of FDI and multinational firms on equilibrium wages in host countries. Even when we examined reasons for multinationals to pay above-equilibrium wages, there was no assurance that they would do so. There seems to be a presumption, at least in the case of capital flows, that FDI will raise at least some wages, but even this is not certain, and it becomes even less so when we recognize other forms of multinational activity such as fragmentation. It is therefore an empirical question whether the actual operations of multinationals have raised or lowered wages in developing countries. It is to that empirical question that we now turn. 


\section{Effects on Wages and Working Conditions: What are the Facts?}

In keeping with the broad conceptual focus in the preceding section, we turn now to a review of the empirical evidence on wages and working conditions associated with multinationals. ${ }^{40}$ We first consider the effects on wages and thereafter the relationship between FDI and labor rights broadly conceived.

\section{Foreign Ownership and Wages}

The published evidence on the effects of foreign ownership on wages in developing countries is based on ad hoc observations and surveys as well as a number of studies using econometric methods.

Lim (2001, pp. 39-40) provides a useful summary of some evidence that foreign-owned and subcontracting firms in manufacturing industries tend to pay higher wages than domestic firms: ${ }^{41}$

- Affiliates of U.S. multinational enterprises pay a wage premium that ranges from 40 percent in high-income countries to 100 percent, or double the local average in low-income countries. ${ }^{42}$ Graham (2000)

- Workers in foreign-owned and subcontracting apparel and footwear factories in Vietnam rank in the top 20 percent of the population by household expenditure. Glewwe (2000)

- In Nike subcontractor factories in June/July 2000, annual wages were $\$ 670$ compared with an average minimum wage of $\$ 134$. In Indonesia, annual wages were $\$ 720$ compared with an average annual minimum of \$241. Lim (2000)

- In Bangladesh, legal minimum wages in export processing zones are 40 percent higher than the national minimum for unskilled workers, 15 percent higher for semi-skilled workers, and 50 percent higher for skilled workers. Panos (1999)

- In Mexico, firms with between 40 and 80 percent of their total sales going to exports paid wages that were, at the low end, 11 percent higher than the wages of non-export oriented firms; for companies with export sales above 80 percent, wages were between 58 and 67 percent higher. Lukacs (2000)

- In Shanghai, a survey of 48 U.S.-based companies found that respondents paid an average hourly wage of $\$ 5.25$, excluding benefits and bonuses, or about $\$ 10,900$ per year. At a jointly-owned

\footnotetext{
${ }^{40}$ In his conference comment, André Sapir suggested that we should have focused more narrowly on the production, trade, wages, and working conditions in the apparel industry and on the respective roles of multinational firms and subcontractors. While Sapir's suggestion is well taken, the approach that we took was designed to provide a broader context for the conceptual and empirical issues involved.

${ }^{41}$ See also Kristof and WuDunn (2000). Much of the available information evidently refers to wages in manufacturing. It would be useful accordingly to obtain information on wages paid by foreign-owned and subcontracting industries in extractive industries such as mining and in service industries in different developing countries.

${ }^{42}$ It may be noted further, according to $\operatorname{OECD~(2001,~Fig.~8)~that~compensation~per~employee~of~firms~under~foreign~}$ control in the OECD countries was substantially higher than the average for national firms.
} 
GM factory in Shanghai, workers earned $\$ 4.59$ an hour, including benefits; this is about three times higher than wages for comparable work at a non-U.S. factory in Shanghai. Lukacs (2000))

According to a report on Nike contract factories in Vietnam and Indonesia by students from The

Amos Tuck School at Dartmouth College, Calzini et al. (1997, p. 2):

- For factory workers living on their own, Nike contract factory wages allow workers to generate discretionary income in excess of basic expenditures such as food, housing, and transportation.

- For workers living in extended-family households, Nike contract factory wages are used to augment total household income to raise overall living standards.

- Nike contract factory workers consistently earn wages at or above government-mandated minimum wage levels.

- Given the employment opportunities available, Nike contract factories offer an economically attractive alternative for entry-level workers. Nike contract factory jobs provide workers a consistent stream of income in contrast to common alternatives such as farming or shop-keeping. There are significantly more applicants than factory positions available.

- In Indonesia, non-cash benefits provided help to offset recurring expenses for food, housing, and transportation.

- In Vietnam, overtime wages are perceived by workers to be an attractive means to supplement base income levels.

Moran (2002, Ch. 1, 2) provides extensive evidence on wages and related benefits of FDI and for-

eign-originated subcontracting in low-skill and low-wage sectors in developing countries as follows:

- The ILO (1998) finds, based on worker surveys, that wages paid in export-processing zones (EPZs) are higher than in the villages from which workers are typically recruited.

- The U.S. Department of Labor (2000) finds that footwear and apparel manufacturers in selected countries pay higher wages and offer better working conditions than those available in agriculture.

- The International Youth Foundation (2000) surveyed three footwear and two apparel factories in Thailand and found that 72 percent regarded their wages as "fair" and 60 percent were able to accumulate savings.

- Bhattacharya (1998) reports that garment workers in Bangladesh earn 25 percent more than the country's average per capita income.

- Razafindrakoto and Roubaud (1995, p. 226) find that EPZ workers in Madagascar earned 15-20 percent more than the average worker in the rest of the economy even after controlling for education level, extent of professional experience, and tenure in employment. 
- Workers in the Philippine EPZ reported themselves to be better off after finding employment in the EPZ during the 1990s. As reported by the World Bank (1998, Appendix C), 47 percent of workers earned enough to have some savings, as compared to 9 percent before employment in the zone. In addition, employees received social security, medical care, paid vacation, sick leave, maternity leave, and other employee benefits.

Let us next consider some econometric-based evidence on the wage effects of multinationals. The earliest evidence grew out of a literature examining the role of FDI in transmitting technology internationally. The impact of FDI on wages was used as an indication that technological know-how raises labor productivity. For example, Aitken, Harrison, and Lipsey (1996) explored the impact of foreign ownership in Mexico, Venezuela and the United States. They found that the presence of foreign ownership significantly raises wages within the plant in all three countries, but the impact spills over into locally-owned plants only in the United States.

For all three countries, manufacturing survey data were analyzed. In the case of Mexico, 2,113 plants were surveyed concerning factor usage, sales, equity ownership, and input and output prices. Data were also available on industry and location. For Venezuela, data were available on foreign ownership, assets, employment, input costs, and location for all plants employing more than 50 workers. The log of the industry/region average wage was regressed on the proportion of employment in foreign-owned firms within the industry-region, a measure of the capital stock, royalty payments, and average output and input prices. Aitken et al. found that a 10 percent increase in the share of foreign investment in regional/industry employment raised wages on the order of 2.5 percent in Mexico and Venezuela. However, when the analysis was restricted to domestic-owned firms, the foreign investment variable was insignificant.

The empirical analysis was then performed at the plant level, incorporating information on plant size and age. As with the industry-level analysis, the extent of foreign ownership raised wages of both skilled and unskilled workers, with the impact on skilled workers about 50 percent higher than for unskilled workers. However, as will be seen in the case for Indonesia noted below, about one third of the wage-premium paid by foreign-owned firms was accounted for by larger plant size. 
In order to identify the source of the FDI wage premium, Aitken et al. analyzed a cross-section of firms for Venezuela and the United States in 1987 and Mexico in 1990. They took as a point of departure that foreign-owned firms in all three countries paid about 30 percent more than domestic firms for both skilled and unskilled labor. Controlling for industrial sector, they first found that this accounted for a significant portion of the FDI wage premium. That is, foreign firms tended to locate in higher-paying sectors of the economy. For the United States, industry effects accounted for about half of the premium. In Mexico the figure was two-thirds and for Venezuela the figure was one-third. They then considered location. In the case of the United States, foreign-owned firms actually tended to locate in low-wage regions. As a consequence, controlling for region made the FDI wage premium larger. However, foreign affiliates were located in high wage regions of Venezuela and Mexico. Nevertheless, even after controlling for region, foreign-owned firms paid more than domestic firms. Finally, Aitken et al. controlled for plant size and capital intensity. Foreign-owned firms tended to operate larger facilities, giving rise to economies of scale that may raise wages. However, as with location and industry, the foreign ownership variable retained some explanatory power. Unfortunately, Aitken et al. did not report regression results in which they controlled simultaneously for industry, location, plant size, and capital intensity. As a consequence, it is not possible to tell whether foreign ownership serves as a proxy for the omitted variables in each equation. Nevertheless, the Aitken et al. results support the view that foreign-owned firms pay premium wages.

Further supporting evidence is found by Feenstra and Hanson (1997) in their study of the impact of foreign owned capital on the skilled-labor wage premium in Mexico for the period 1975-1988. They found in particular that foreign capital impacts the demand for skilled labor disproportionately. FDI constitutes a significant and growing portion of the capital stock in Mexico. In 1987, FDI accounted for 13.7 percent of total fixed investment in Mexico, a level sufficient to affect the demand for labor. A surge in investment in the border region occurred following liberalization measures enacted by Mexico between 1982 and 1985. Rules prohibiting majority foreign ownership were relaxed, and the average tariffs were lowered from 23.5 to 11.8 percent. In the immediate aftermath, the share of FDI in total investment in 
Mexico rose nearly six-fold. At the same time, the wages of skilled and unskilled workers began to diverge after nearly 20 years of convergence.

In order to test whether FDI in the maquiladoras contributed to the growing wage disparity in Mexico during the 1980s, Feenstra and Hanson analyzed labor-market census data for nine 2-digit ISIC categories in 32 states for the three periods, 1975-1980, 1980-1985, and 1985-1988. The nonproduction wage bill as a fraction of the total wage bill was regressed on a measure of alternative wages for skilled and unskilled workers, the state's domestic capital stock, and the ratio of maquiladoras in a state to the number of domestically-owned establishments. They found that the fraction of establishments that are foreign-owned significantly raised the relative return to skilled labor. Between 1985 and 1988, FDI accounted for 52.4 percent of the increase in the wage share of nonproduction workers in the border region.

Although Feenstra and Hanson's results are informative, they focus primarily on the impact that foreign ownership has on the demand for labor in local factor markets, thereby providing little evidence on the specific labor practices of multinational firms. The evidence presented above supports the view that multinational firms are improving the lives of at least some workers by raising overall labor demand. However, in order to respond to some of the challenges raised by the issue of sweatshop labor, we might also want to know whether foreign-owned firms play a positive role by altering industry characteristics or by paying above-market wages.

To this end, Lipsey and Sjöholm (2001) analyzed the wages paid by foreign-owned plants in Indonesia. $^{43}$ They were specifically interested in whether foreign-owned firms pay more for local workers than do domestic firms and, if so, why. Can the difference be attributed to plant characteristics, worker characteristics, or industry characteristics? Further, do the labor practices of multinationals affect the wages paid by local firms? Lipsey and Sjöholm analyzed survey evidence for all plants in Indonesia that had more than 20 employees. In 1996, 19,911 plant managers responded to the survey, providing data on value-added, energy inputs, location, and labor characteristics for blue collar and white-collar workers.

\footnotetext{
${ }^{43}$ Hill (1990) and Manning (1998) also find that foreign firms pay higher wages than domestic firms in Indonesia.
} 
Lipsey and Sjöholm used the plant-level data to estimate a standard wage equation. The log of the average plant-level wage was regressed on average education level (as measured by proportion of workers with primary, junior, senior, and university education), plant characteristics including size, proportion of workers that are female, energy inputs, other inputs, and binary variables for foreign ownership, government ownership, sector, and location.

Three separate wage equations were estimated. First, Lipsey and Sjöholm controlled only for ownership and education level. They found that foreign-owned firms paid 33 percent more for blue-collar workers and 70 percent more for white-collar workers than locally owned firms. So the next question was, what is it about foreign-owned firms that produces the premium? When the region and sector dummy variables were added to the regression equation, the premium fell to 25 percent for blue-collar workers and 50 percent more for white-collar workers. Finally, controlling for plant size, energy inputs per worker, other inputs per worker and the proportion of employees that is female, the foreign-ownership premium fell to 12 percent for blue-collar and 22 percent for white-collar workers. So, about one-third of the foreign-ownership premium for labor of a specific quality was accounted for by region and industry, one-third by inputs and plant size, leaving one-third of the premium unexplained. Thus, foreign-owned firms are raising wages for blue-collar and white-collar workers above and beyond the impact of increased productivity associated with more inputs per worker and a more efficient scale of production.

Lipsey and Sjöholm suggested several reasons why foreign-owned firms might pay a higher wage for the same quality of labor and in the same industrial setting. One possibility, of course, is that they are responding to social pressure to combat desperately poor working conditions. However, foreign-owned firms may have less knowledge of the local market, want to invest in the skills of their employees, or fear the loss of competitive advantage to locally-owned firms. Alternatively, workers may prefer domesticowned firms, requiring foreign firms to pay a premium.

Lipsey and Sjöholm also considered whether the presence of FDI raises the wages in domestically-owned plants. They regressed the log of wages in domestically-owned plants on worker, plant, and industry characteristics, but also included a variable indicating the proportion of industry value-added 
produced in foreign-owned plants. In contrast to the results obtained by Aitken et al. in the case of Mexico and Venezuela, the presence of foreign owned firms in an industry significantly affected the wages paid by domestically owned firms in Indonesia. This was the case whether industries were defined at the 2-, 3- or 5-digit level.

Given these findings that foreign-owned firms pay higher wages even after controlling for scale, worker quality, industry, age of facility, inputs and industry and regional characteristics, one might wonder whether firms are motivated by humanitarian concerns or public pressure. Similarly, foreign-owned firms could be more likely to conform with laws regulating minimum wages, overtime pay, and benefits. However, if humanitarian concern or public and legal pressure are the motivating factors, we might expect that the impact would be most pronounced for the most poorly paid workers. However, this is not the case. That is, the largest bonus for working with foreign capital apparently accrues to skilled/whitecollar workers in the form of higher wages. Thus, while foreign capital may raise wages on average, it may also tend to worsen the distribution of income between skilled and unskilled workers.

Alternatively, it has been suggested (as discussed above) that foreign firms pay premium wages for unobservable characteristics such as intelligence, flexibility or discipline. Employees who reveal these capabilities after they are hired are likely to be retained with higher-than-average compensation.

However, it is important to note first that there is considerable evidence that the FDI wage premium is a consequence of total factor and labor productivity gains associated with foreign ownership. In this connection, a positive correlation between productivity gains and foreign ownership was found by: Aitken and Harrison (1993) for Venezuela; Haddad and Harrison (1993) for Morocco; Harrison (1993) for Cote d'Ivoire; and Luttmer and Oks (1993) for Mexico.

Furthermore, Budd and Slaughter (2000) and Budd, Konings, and Slaughter (2001) present evidence that multinationals share profits with local and foreign workers. They find, in particular, that affiliate wages are positively correlated with parent profits. They argue that such profit sharing is profitmaximizing in a model in which both workers and firms are risk-averse. Profit sharing will also emerge 
if wages are set in a bargaining framework in which the firm's ability to pay depends positively on profitability.

\section{Foreign Direct Investment and Labor Rights}

In addition to the controversy about the effects of multinationals on wages, it is often argued that they are attracted to markets where worker rights are poorly protected. That is, multinationals are alleged to seek out havens safe from union activism, and there is no shortage of governments willing to accommodate the interests of foreign capital. The allegation stems in part from the view that foreign firms have lower labor costs in locations with weak labor protections. Indeed, several studies find that FDI is attracted to regions with low labor cost after controlling for productivity.

Studies of the role of labor costs in foreign investment decisions provide ambiguous evidence, with some studies finding a positive correlation and others a negative correlation. (See for example: Schneider and Frey (1985); Jun and Singh (1997); Wheeler and Moody (1992); Billington (1999); Cooke and Noble (1999); and Head, Ries, and Swenson (1999)). However, these studies all suffer from the weakness that they do not control for labor productivity. As a consequence, studies that find a positive correlation between wages and FDI, without controlling for productivity, suffer from the weakness that wages are probably a proxy for productivity rather than labor costs.

In contrast, Culem (1988), in an analysis of bilateral FDI flows among a selection of industrialized countries between 1969 and 1982, found that FDI was significantly adversely affected by high labor costs once output per worker was introduced as an explanatory variable. Similarly, Friedman, Gerlowski and Silberman (1992) found that the allocation of FDI across individual states in the United States between 1977 and 1988 was significantly affected by the relative labor costs of individual states, after controlling for state-level labor productivity.

However, in a recent survey of managers of transnational corporations reported by Hatem (1997), several other factors were considerably more important than labor cost when selecting a site for FDI. Market size, political and social stability, labor quality, the legal and regulatory environment, and infra- 
structure were all rated as more important than the cost of labor. Labor rights that promote political stability and enhance labor quality may in fact make a particular location attractive to foreign investors.

For this reason, it is useful to separate the role that worker rights play in raising labor costs relative to labor productivity from those that improve the efficient functioning of a production facility. For example, Head, Ries, and Swenson (1999) found that the unionization rate in a U.S. state lowered the inflow of Japanese investment. Cooke and Noble (1999) found similar adverse effects of unionization in developing countries. However, Friedman, Gerlowski and Silberman (1992) found that Japanese firms were more likely to locate a plant in a U.S. state with a high unionization rate after controlling for wages and productivity. Thus, it seems that, as long as the union does not raise wages above worker productivity, Japanese firms appear to believe that unions play a positive role in the plant.

Of course, worker rights are not limited to collective bargaining. The empirical evidence on worker rights more broadly defined is unambiguous. No matter how worker rights are defined, foreign investors do not appear to be attracted to countries with poorly protected worker rights. Similarly, political and social stability have a positive impact on the choices of foreign investors.

Cooke and Noble (1999) found that U.S. outward FDI was positively correlated with the number of ILO conventions ratified. OECD (2000) found that FDI was positively correlated with the right to establish free unions, the right to strike, the right to collective bargaining, and protection of union members. Rodrik (1996) found that U.S. outward FDI between 1982 and 1989 was positively correlated with a Freedom House democracy index but was deterred by a high index of child labor. This was the case even though countries with a high democracy index and a low child-labor index had higher labor costs.

The work on FDI and worker rights has been criticized on two counts. Martin and Maskus (2001) in particular note the problems with relying on ILO conventions ratified and the Freedom House indicators of democracy. Furthermore, the studies listed above did not control for other determinants of FDI. Kucera (2001) has attempted to improve on the existing literature on worker rights and labor costs by using multiple definitions of each type of worker rights. 
Following Rodrik, Kucera first regressed the log of wages per employee on value added per employee in manufacturing, GDP per capita, manufacturing share of GDP, the urbanization rate, and multiple measures of freedom of association and collective bargaining, child labor, and gender inequality. Data were for the period 1992-97 in a sample of 127 countries, including 27 "high income economies" and 100 LDCs. First, like Rodrik (1999), Kucera found that wages were positively correlated with all of the measures of political freedom. Surprisingly, the unionization rate had an insignificant negative impact on wages. However, other measures of free association and collective bargaining rights had a positive impact on wages. These measures may be more meaningful since they are based on observed rights violations. The evidence on child labor and wages was quite curious. First, wages were positively correlated with labor-force-participation rates for 10-14 year olds. The coefficient on the secondary non-enrollment rate was also positive. Kucera noted that it is difficult to interpret such results. Finally, in countries where the female proportion of the labor force was higher than average, wages were lower than average. However, this effect was not generally statistically significant.

Kucera then turned to estimate the impact of worker rights on FDI. Each country's share of world FDI inflows was regressed on wages relative to value-added in manufacturing, population, per capita GDP, international trade's share of GDP, exchange rate growth, urbanization, literacy, and the measures of worker rights. He found several very interesting results for the cross-section of all countries as well as for the LDCs separately:

(1) FDI is attracted to countries with a higher civil liberties index even though labor costs are higher. An increase in the civil-liberties index of one unit (on a 10-point scale), controlling for wages, is associated with an 18.5 percent increase in FDI flows. When the negative impact of increased wages in democracies is factored in, a one-unit increase in the civil-liberties index raises FDI inflows by 14.3 percent. So even though democracies pay higher wages for a given level of worker productivity, they still provide an attractive location for foreign investors.

(2) Unionization rates are positively correlated with FDI, controlling for wages relative to labor productivity in equations that also include regional dummies.

(3) FDI is higher in countries with fewer episodes in which rights to free association and collective bargaining are repressed.

(4) FDI is negatively correlated with labor-force participation rates for 10-15 year olds. Otherwise results are mixed and not statistically significant. 
(5) Measures of gender discrimination are not statistically significant.

In short, there is no solid evidence that countries with poorly protected worker rights attract FDI.

If anything, investors apparently prefer locations in which workers and the public more generally function in a stable political and social environment in which civil liberties are well established and enforced. ${ }^{44}$

This evidence is also consistent with FDI causing improvements in worker rights and working conditions. As we noted in our theoretical discussion earlier in the paper, the same forces that may lead multinational firms to pay higher wages are likely in equilibrium to improve working conditions as well.

\section{Conclusions}

The popular press is rife with anecdotes about foreign workers who labor for multinational firms for low wages and for excruciating long hours under horrific conditions in low-income countries to produce goods for Western consumers. This negative impression that multinationals are exploiting and mistreating their workers is reinforced by calculations that labor costs are typically a tiny fraction of the retailselling price of the goods being produced, and that the multinationals therefore can and should pay higher wages to their workers.

It is true that, as a theoretical matter, multinationals can have an array of positive and negative impacts on host-country workers. However, as an empirical matter, some anecdotal evidence notwithstanding, there is virtually no careful and systematic evidence demonstrating that, as a generality, multinational firms adversely affect their workers, provide incentives to worsen working conditions, pay lower wages than in alternative employment, or repress worker rights. In fact, there is a very large body of empirical evidence indicating that the opposite is the case. Foreign ownership raises wages both by raising labor productivity and expanding the scale of production, and, in the process, improving the

${ }^{44}$ A caveat to this conclusion is that it is based in large measure on cross-section regression analysis and may therefore not apply directly to individual countries such as mainland China, which is a major recipient of FDI even though it may lack the worker protection and civil liberties found in many other developing countries. However, in a separate communication based on the regression residuals in his analysis, Kucera has informed us that: "All in all, the results suggest that China does not receive so much FDI because of its weak FACB [freedom of association and collective bargaining] rights." It should also be mentioned that most empirical studies do not clearly distinguish FDI for export purposes and FDI to serve the host-country market. Further, most studies treat manufacturing in the aggregate and thus lack the sectoral detail of interest, especially for the relatively labor-intensive industries such as apparel and footwear that are the focus of the anti-sweatshop activists. 
labor productivity and expanding the scale of production, and, in the process, improving the conditions of work. Furthermore, there appears to be some evidence that foreign-owned firms make use of aspects of labor organizations and democratic institutions that improve the efficiency characteristics of their factory operations.

It is undoubtedly the case that public pressure can and ought to be brought to bear on some multinational firms and their suppliers who are abusing social norms to the detriment of their workers. But great care needs to be exercised since, generally, measures that are punitive or provide firms an incentive to alter the location of production are unwarranted and may adversely affect the very workers they are intended to benefit.

\section{References}

Aitken, Brian and Ann Harrison. 1993. "Does Proximity to Foreign Firms Induce Technology Spillovers." PRD Working Paper (World Bank).

Aitken, Brian, Ann Harrison, and Robert E. Lipsey. 1996. "Wages and Foreign Ownership: A Comparative Study of Mexico, Venezuela, and the United States," Journal of International Economics 40:345-371.

Bhagwati, Jagdish. 2001. "Thinking Responsibly about Social Responsibility," World Link (February).

Bhattacharya, Debapriya. 1998. Export Processing Zones in Bangladesh: Economic Impact and Social Issues. Geneva: International Labor Office, Working Paper No. 80.

Billington, Nicholas. 1991. "The Location of Foreign Direct Investment: An Empirical Analysis." Applied Economics 31: 65-76.

Broad, Robin (ed.). 2002. Global Backlash: Citizen Initiatives for a Just World Economy. Boulder and New York: Rowman and Littlefield Publishers, Inc.

Brown, Drusilla K., Alan V. Deardorff, and Robert M. Stern. 2002. "Pros and Cons of Linking Trade and Labor Standards," forthcoming in Douglas R. Nelson, The Political Economy of Policy Reform.

Budd, John W., Jozef Konings, and Matthew J. Slaughter. 2002. "International Rent Sharing in Multinational Firms," NBER Working Paper 8809, Cambridge: National Bureau of Economic Research.

Budd, John W., and Matthew J. Slaughter. 2000. "Are Profits Shared Across Borders? Evidence on International Rent Sharing," NBER Working Paper 8014, Cambridge: National Bureau of Economic Research. 
Business for Social Responsibility Education Fund, Investor Responsibility Research Center, and Dara O’Rourke. 2000. Independent University Initiative: Final Report.

Calzini, Derek, Jake Odden, Jean Tsai, Shawna Huffman, and Steve Tran. 1997. "Survey of Vietnamese and Indonesian Domestic Expenditure Levels, Nike Inc.," Field Studies in International Business, The Amos Tuck School, Dartmouth College.

Card, David and Alan Krueger. 1995. Myth and Measurement: The New Economics of the Minimum Wage. Princeton: Princeton University Press.

Carr, David L., Markusen, James R., and Keith E. Maskus. 2001. "Estimating the Knowledge-Capital Model of the Multinational Enterprise," American Economic Review 91:693-708.

Connor, Melissa et al. 1999. "The Case for Corporate Responsibility: Paying a Living Wage to Maquila Workers in El Salvador," A Study for the National Labor Committee, Program in Economic and Political Development, School of International and Public Affairs, Columbia University. Available at: www.nlcnet.org/elsalvador/sipareport.htm.

Cooke, William and Deborah Noble. 1998. "Industrial Relations Systems and U.S. Foreign Direct Investment Abroad." British Journal of Industrial Relations 34:581-609.

Cooper, Helene. 2001. “Madagascar's Textile Sector Draws Fresh Life from U.S. Trade Move," The Wall Street Journal on Line (WSJ.com).

Culum, Claude. 1988. "The Locational Determinants of Direct Investments among Industrialized Countries." European Economic Review 32:885-904.

Deardorff, Alan V. 2000 "Patterns of Trade and Growth Across Cones," De Economist 148, (June), pp. 141-166.

Deardorff, Alan V. 2001a "Fragmentation across Cones," in Sven W. Arndt and Henry Kierzkowski (eds.), Fragmentation: New Production Patterns in the World Economy, Oxford: Oxford University Press.

Deardorff, Alan V. 2001b "Fragmentation in Simple Trade Models," North American Journal of Economics and Finance 12:121-137.

Elliott, Kimberly Ann and Richard B. Freeman. 2001. "White Hats or Don Quixotes? Human Rights Vigilantes in the Global Economy," National Bureau of Economic Research, Working Paper 8102 (January).

Feenstra, Robert C. and Gordon H. Hanson. 1996. "Foreign Investment, Outsourcing, and Relative Wages," in Robert C. Feenstra, Gene M. Grossman, and Douglas A Irwin (eds.), The Political Economy of Trade Policy: Essays in Honor of Jagdish Bhagwati. Cambridge, MA: MIT Press.

Feenstra, Robert C. and Gordon H. Hanson. 1997. "Foreign Direct Investment and Relative Wages: Evidence from Mexico’s Maquiladoras.” Journal of International Economics 42:371-393.

Freeman, Richard B. 1993. "Labor Market Institutions and Policies: Help or Hindrance to Economic Development?" Proceedings of the World Bank Annual Conference on Development Economics 1993, pp. 117-44. 
Friedman, J., D. Gerlowski and J. Silberman. 1992. "What Attracts Foreign Multinational Corporations? Evidence from Branch Plant Location in the United States." Journal of Regional Science 32:403418.

Glewwe, Paul. 2000. “Are Foreign-Owned Businesses in Viet Nam Really Sweatshops?” in University of Minnesota Extension Service Newsletter, No. 701 (Summer).

Graham, Edward M. 2000. Fighting the Wrong Enemy: Antiglobal Activists and Multinational Enterprises. Washington, D.C.: Institute for International Economics.

Haddad, M. and Ann Harrison. 1993. "Are there Positive Spillovers from Direct Foreign Investment? Evidence from Panel Data for Morocco.” Journal of Development Economics, October.

Harris, John R. and Michael P. Todaro. 1970. "Migration, Unemployment and Development: A TwoSector Analysis," American Economic Review 60:126-142.

Harrison, Ann. 1996. "Foreign Investment in Three Developing Countries : Determinants and Consequences, in M. Roberts and J. Tybout (eds.), Industrial Evolution in Developing Countries: Micro Patterns of Turnover, Productivity and Market Structure. New York: Oxford University Press.

Harvard Magazine. 2001. “Ways and Means: Harvard's Wage Debate," November-December [www.Harvard-magazine.com/on-line/110182.html].

Hatem, Fabrice. 1997. International Investment: Towards the Year 2001. United Nations.

Head, C. Keith, John Ries, and Deborah Swenson. 1999. "Attracting Foreign Manufacturing: Investment Promotion and Agglomeration." Regional Science and Urban Economics 29:197-218.

Helpman, Elhanan. 1984. "A Simple Theory of International Trade with Multinational Corporations," Journal of Political Economy 92: 451-71.

Hill, Hal. 1990. “Indonesia's Industrial Transformation Part II," Bulletin of Indonesian Economic Studies 26:75-109.

ILO. 1998. Labor and Social Issues Relating to Export Processing Zones. Geneva: ILO.

International Youth Foundation. 2002. Needs Assessment For Workers and Communities. Research conducted by the Chulalongkorn University Social Research Unit, Sponsored by the Global Alliance for Workers and Communities.

Jun, Kwang and Harinder Singh. 1997. "The Determinants of Foreign Direct Investment: New Empirical Evidence." Transnational Corporations 5:67-105.

Katz, Lawrence F. and Lawrence H. Summers. 1989. "Industry Rents: Evidence and Implications," Brookings Papers on Economic Activity, 209-275.

Kristof, Nicholas D. and Sheryl WuDunn. 2000. "Two Cheers for Sweatshops," The New York Times Magazine, (September 24). [http://www.fordschool.umich.edu/rsie/acit/ProViews.html]

Krueger, Anne O. 1977. Growth, Distortions, and Patterns of Trade Among Countries, Princeton Studies in International Finance, No. 40, (Princeton). 
Krugman, Paul R. 2000. "Technology, Trade, and Factor Prices," Journal of International Economics 50:51-71.

Kucera, David. 2001. “The Effects of Core Worker's Rights on Labour Costs and Foreign Direct Investment: Evaluating the 'Conventional Wisdom." Decent Work Research Programme EP/130/2001, International Labour Organization.

Leamer, Edward E. 1999. "Effort, Wages and the International Division of Labor," Journal of Political Economy 107:1127-1162.

Leamer, Edward E. and James Levinsohn. 1995. "International Trade Theory: The Evidence," in Gene M. Grossman and Kenneth Rogoff (eds.), Handbook of International Economics, Vol. III. Amsterdam: North-Holland.

Lim, Linda Y.C. 2000. "My Factory Visits in Southeast Asia and UM Code and Monitoring," September 6. [http://www.fordschool.umich.edu/rsie/acit/ProViews.html]

Lim, Linda Y.C. 2001. The Globalization Debate: Issues and Challenges. Geneva: International Labour Organization.

Lipsey, Robert E. and Fredrik Sjöholm. 2001. "Foreign Direct Investment and Wages in Indonesian Manufacturing," NBER Working Paper No. 8299 (May).

Lukacs, Aaron. 2000. WTO Report Card III: Globalization and Developing Countries, Trade Briefing Paper. Washington, D.C: Center for Trade Policy Studies, Cato Institute

Luttmer, E. and D. Oks. 1993. Productivity in Mexican Industries. Washington, D.C.: World Bank.

Manning, Chris. 1998. Indonesian Labour in Transition: An East Asian Success Story? Cambridge: Cambridge University Press.

Markusen, James R. 1984. "Multinationals, Multiplant Economies, and the Gains from Trade," Journal of International Economics 16:205-226.

Martin, Will and Keith Maskus. 2001. "The Economics of Core Labor Standards: Implications for Global Trade Policy," Review of International Economics 9:317-28.

Moran, Theodore. 2002. Beyond Sweatshops: Foreign Direct Investment in Developing Countries. Washington, D.C.: Brookings Institution, forthcoming.

Neumark, David. 2002. How Living Wage Laws Affect Low-Wage Workers and Low-Income Families. San Francisco: Public Policy Institute of California.

OECD. 2000. International Trade and Core Labour Standards. Paris: OECD.

OECD. 2001. Measuring Globalization: The Role of Multinationals in OECD Economies, Vol. I: Manufacturing Sector. Paris: OECD.

Panos. 1999. Globalization and Employment: New Opportunities, Real Threats. Panos Briefing No. 33 (May). 
Razafindrakoto, Mireille and Francois Roubaud. 1995. "Les Entreprises Franches a Madagascar: Economie d'enclave ou promesse d'une novelle prosperité? Mouvel exclavage ou opportunité pour le developpement du Pays?" Economie de Madagascar, No. 2.

Rodrik, Dani. 1996. "Labor Standards in International Trade: Do They Matter and What Do We Do About Them?" in Robert Lawrence, Dani Rodrik, and John Whalley (eds.), Emerging Agenda for Global Trade: High Stakes for Developing Countries. Washington, D.C.: Overseas Development Council.

Rodrik, Dani. 1999. “Democracies Pay Higher Wages,” Quarterly Journal of Economics 114:707-738.

Ruggie, John Gerard. 2002. "The Theory and Practice of Learning Networks: Corporate Social Responsibility and the Global Compact," JCC 5:27-36, Greenleaf Publishing.

Schneider, Friedrich and Bruno Frey. 1985. "Economics and Political Determinants of Foreign Direct Investment." World Development 13(2): 161-175.

Srinivasan, T. N. 1998. "Trade and Human Rights," in Alan V. Deardorff and Robert M. Stern (eds.), Constituent Interests and U.S. Trade Policies. Ann Arbor: University of Michigan Press.

Srinivasan, T. N. 2001. "Living Wage in Poor Countries," manuscript.

The New York Times. 2002. "Mexico is Attracting a Better Class of Factory in Its South," June 29, p. A3.

The Wall Street Journal. 2002. "Newly Aggressive Labor Groups Pressure Corporate Indonesia," August 14, p. A11.

U.S. Department of Labor, Bureau of International Labor Affairs. 2000. Wages, Benefits, Poverty Line, and Meeting Workers' Needs in the Apparel and Footwear Industries of Selected Countries. Washington, D.C.

University of Chicago Magazine. 2000. "Student Activists Raise Signs Over Sweatshops," June. [http://www.fordschool.umich.edu/rsie/acit/NeuViews.html]

University of Michigan. 2000. The Final Report of the Advisory Committee on Labor Standards and Human Rights (May). Available at: www.Fordschool.umich.edu/rsie/ACIT.

Varley, Pamela (ed.). 1998. The Sweatshop Quandary: Corporate Responsibility on the Global Frontier. Washington, D.C.: Investor Responsibility Research Center.

Verité. 2000. Pilot Project for Licensing Labor Code Implementation, Final Report (October 3)

Verité. 2001. Comprehensive Factory Evaluation Report Prepared by Verite on Kukdong International Mexico, S.A. de C.V., Atlixco, Puebla, Mexico (February 5-7).

Wheeler, David and Ashoka Mody. 1992. "International Investment Location Decisions: The Case of U.S. Firms," Journal of International Economics 33:57-76.

World Bank. 1999. The Philippines: The Case of Economic Zones, Washington, D.C. 
World Trade Organization. 1998, 2000. International Trade Statistics 2001, Geneva.

Yellen, Janet L. 1984 "Efficiency Wage Models of Unemployment," American Economic Review Papers and Proceedings 74:200-205. 


\begin{tabular}{|c|c|c|c|}
\hline \multicolumn{4}{|c|}{$\begin{array}{c}\text { Table } 1 \\
\text { Effect of FDI as Capital Flow on }\end{array}$} \\
\hline \multicolumn{2}{|l|}{ Model (sectors $\times$ factors) } & $\begin{array}{c}\text { Small } \\
\text { Country }\end{array}$ & $\begin{array}{l}\text { Two-Country } \\
\text { Model }^{\mathrm{b}}\end{array}$ \\
\hline \multicolumn{2}{|l|}{ One-sector $(1 \times 2)$} & + & + \\
\hline \multicolumn{2}{|l|}{ HO $(2 \times 2)$ diversified } & 0 & 0 \\
\hline \multicolumn{2}{|l|}{$\mathrm{HO}(2 \times 2)$ specialized } & + & + \\
\hline \multicolumn{2}{|l|}{ Specific Factors $(2 \times 3)$} & + & + \\
\hline \multicolumn{2}{|c|}{$\mathrm{HO}(3+\times 2)$ two-cone, diversified } & 0 & + \\
\hline \multirow{2}{*}{$\begin{array}{l}\text { Feenstra-Hanson }(\infty \times 3) \\
\text { two-cone, diversified }\end{array}$} & Skilled labor & + & + \\
\hline & Unskilled labor & + & - \\
\hline
\end{tabular}

${ }^{a}$ The small country is defined by facing world prices that are fixed independently of what it produces.

${ }^{\mathrm{b}}$ In the two-country model, FDI here takes the form of an increase in the capital stock of the host country and an equal decrease in the capital stock of the other country.

\begin{tabular}{|l|l|c|}
\hline \multicolumn{3}{|c|}{ Table 2 } \\
\hline \multirow{3}{*}{ Effect of FDI as Technology Flow on Host-Country Wage } \\
\hline \multirow{2}{*}{ One-sector $(1 \times 2)$} & Nature of technology change & $\begin{array}{c}\text { Effect on } \\
\text { wage }\end{array}$ \\
& Neutral $\times$ factors $)$ & + \\
\cline { 2 - 3 } & Labor using & + \\
\cline { 2 - 3 } HO $(2 \times 2)$ diversified & Labor saving & + or - \\
\cline { 2 - 3 } & In labor-intensive sector & + \\
\hline $\begin{array}{l}\text { HO }(3+\times 2) \text { two-cone, } \\
\text { diversified }\end{array}$ & In labor-intensive sector of cone & + \\
\cline { 2 - 3 } & In capital-intensive sector of cone & - \\
\hline
\end{tabular}

